This item was submitted to Loughborough's Research Repository by the author.

Items in Figshare are protected by copyright, with all rights reserved, unless otherwise indicated.

\title{
Psychosocial functioning of Olympic coaches and its perceived effect on athlete performance: a systematic review
}

PLEASE CITE THE PUBLISHED VERSION

https://doi.org/10.1080/1750984x.2020.1802769

\section{PUBLISHER}

Taylor \& Francis

\section{VERSION}

AM (Accepted Manuscript)

\section{PUBLISHER STATEMENT}

This is an Accepted Manuscript of an article published by Taylor \& Francis in International Review of Sport and Exercise Psychology on 13 Aug 2020, available online:

http://www.tandfonline.com/10.1080/1750984X.2020.1802769.

\section{LICENCE}

CC BY-NC-ND 4.0

\section{REPOSITORY RECORD}

Cook, Gillian, David Fletcher, and Christopher Carroll. 2020. "Psychosocial Functioning of Olympic Coaches and Its Perceived Effect on Athlete Performance: A Systematic Review". Loughborough University. https://hdl.handle.net/2134/14223989.v1. 
Psychosocial Functioning of Olympic Coaches and its Perceived Effect on Athlete Performance:

\author{
A Systematic Review \\ Gillian M. Cook and David Fletcher \\ Loughborough University, United Kingdom \\ Christopher Carroll \\ The University of Sheffield, United Kingdom
}

Author Note

Gillian M. Cook and David Fletcher, School of Sport, Exercise and Health Sciences, Loughborough University, Loughborough, United Kingdom; Christopher Carroll, Health Economics and Decision Science, School of Health and Related Research, The University of Sheffield, Sheffield, United Kingdom.

Gillian M. Cook is now at the School of Sport and Exercise Sciences, Liverpool John Moores University, Liverpool, United Kingdom.

Correspondence concerning this article should be addressed to Gillian M. Cook, School of Sport and Exercise Sciences, Liverpool John Moores University, Byrom Street, Liverpool, Merseyside, L3 3AF, United Kingdom. E-mail: G.M.Cook@ljmu.ac.uk 


\begin{abstract}
Effective coaching facilitates an athletes' success in reaching their potential in sport. Coaches possess a range of knowledge, skills and attributes that influence athletes' performance, including various intrapersonal and interpersonal qualities. The purpose of this study is to conduct a systematic review of the research investigating the psychosocial functioning of Olympic coaches and its perceived effect on athlete performance. The review was conducted and reported in accordance with the PRISMA guidelines. The following databases were searched: SPORTDiscus, PsycINFO, PsycARTICLES, ScienceDirect, Scopus, Web of Knowledge, and Medline. The literature search identified 2873 studies which were screened and assessed for eligibility, with the resultant 25 eligible studies being assessed for quality of evidence using the Mixed Methods Appraisal Tool. Convergent meta-integration with thematic analysis was performed by converting quantitative and qualitative data from 207 Olympic coaches and 925 Olympic athletes into relevant themes and patterns. Three core themes of traits, states, and behaviors were identified. Within these themes, 18 traits, 28 states, and 38 behaviors were identified that were perceived to have either a facilitative, debilitative, or non-categorized effect on athlete performance. Future research will help national governing bodies and practitioners develop coach education to enhance Olympic coach effectiveness.
\end{abstract}

Keywords: coach; elite; practice; psychology; sport 
Psychosocial Functioning of Olympic Coaches and its Perceived Effect on Athlete Performance:

\section{A Systematic Review}

The central purpose of sports coaching is to nurture athletes' development, improve all aspects of their performance, and maximize their sporting achievements (Jones \& Kingston, 2013; Lyle \& Cushion, 2016). Numerous definitions of sport coaching exist, but for the purpose of this review it is defined as a dynamic, social, and interpersonal process whereby coaches attempt to positively influence athletes' physical, technical, tactical, and psychological development (cf. Abraham, Collins, \& Martindale, 2006; Chelladurai, 2007; Côté \& Gilbert, 2009; Cushion 2007, 2010; Horn, 2008; Jowett \& Shanmugam, 2016; Lyle, 2002). Coaches operate in a variety of contexts (Cushion, 2010; Lyle, 2002; Trudel \& Gilbert, 2006), with performance coaches aiming to optimize athletes' motivation, learning, well-being, and goalattainment, and supporting athletes to compete in recognized elite competitions such as the Olympic Games (Lyle, 2002; Rynne, Mallett, \& Rabjohns, 2016).

The Summer and Winter Olympic Games, each staged every four years, represent the most challenging and prestigious sporting competitions in the world (Gould \& Maynard, 2009). This is due to their global nature, duration, unique size and multi-sport format, with no other sporting event combining so many sport competitions at the same time and in the same place (Cogan, 2019). The unrivalled scale and spectacle generate enormous public interest and media scrutiny (Fletcher \& Sarkar, 2012), and performing at the Olympic Games has been likened to competing in a crucible, with extraordinary pressure for everyone involved (Haberl \& Peterson, 2006). The enhanced expectations from increases in national funding (Rees et al., 2016), combined with other coach stressors such as their continued employment being contingent on 
athlete performance, creates an environment that is both physically and psychologically draining (Fletcher \& Scott, 2010; Mallett \& Lara-Bercial, 2016).

Sport coaching is a dynamic relational process, with the interpersonal relationship fostered between the coach and athlete at its core (Cushion, 2010; Jowett \& Shanmugam, 2016), and the coach's psychosocial attributes form an integral element of this coaching process. Psychosocial attributes can be described as pertaining to both the psychological and social aspects of a phenomenon (Merriam-Webster, 2016), and these aspects are recognized to be an important component of effective coaching (International Council for Coaching Excellence, 2013). In terms of the development of understanding of this area, McCarthy and Giges (2016) reflected that "research on the psychology of coaching in sport overwhelmingly favors the act of coaching over the person who does the coaching. It seems sensible that, for the betterment of coaching in all sport, the research emphasis should begin with the person who does the coaching" (p. 108). This emphasizes the importance of moving beyond coaches' technical and tactical knowledge, which has been the traditional focus of coach development and research (Lefebvre, Evans, Turnnidge, Gainforth, \& Côté, 2016; Maclean \& Lorimer, 2016), towards an understanding of coaches psychosocial attributes, focusing on who they are, how they think and feel, and how they act within their environment.

Although the primary role of Olympic coaches is to enhance athlete performance, coaches are also performers in their own right (Gould, Greenleaf, Chung, \& Guinan, 2002). Coaches are expected to optimize their own functioning within a highly pressurized resultsoriented culture (Fletcher \& Scott, 2010), manage environmental and organizational issues, and select teams which include athletes and support staff (Rynne et al. 2016; Thelwell, Wagstaff, Rayner, Chapman, \& Barker, 2017). Coaches' psychosocial attributes influence both their own 
performance, and that of the athletes (Amorose, 2007; Jowett \& Meek, 2000; Lyle, 2002;

Mageau \& Vallerand, 2003; Smith, Smoll, \& Cumming, 2007; Vealey, Armstrong, Comar, \&

Greenleaf, 1998). Indeed, the demands and the pressurized conditions have reportedly had a negative influence on some coaches which has then adversely affected athletes, teams, and the wider organization (Grey-Thompson, 2017).

The importance of the psychosocial aspects of coaching was highlighted in Côté and Gilbert's (2009) integrative definition of coaching effectiveness, with the authors arguing that effective coaches contribute to the holistic development of athletes. They proposed that effective coaches possess three domains of knowledge: professional, interpersonal, and intrapersonal. The authors emphasized the importance of interpersonal and intrapersonal knowledge. Interpersonal knowledge refers to the ability to relate to, connect with, and influence others, and intrapersonal knowledge encompasses self-awareness and consistent reflection. Professional knowledge, including pedagogical, technical, and tactical skills, alone will not lead to optimal athlete outcomes because coaching is not performed in a vacuum, and interpersonal and intrapersonal knowledge is also required to manage relationships and the environment, and to reflect on coaching practice.

Research investigating the psychosocial functioning of Olympic coaches has gathered momentum in recent years (e.g., Chroni, Abrahamsen, \& Hemmestad, 2016; Ge, Schinke, Dong, Lu, Si, \& Oghene, 2016; Mallett \& Coulter, 2016). There is now a need for a review which evaluates, amalgamates, and summarizes this evolving body of literature to identify research trends and overarching messages which may not be apparent in individual studies. The knowledge gained will give a more robust understanding of Olympic coaches' psychosocial qualities and provide evidence-based recommendations for training and development programs 
to enhance coach effectiveness (cf. Evans, McGuckin, Gainforth, Bruner, \& Côté, 2015). Indeed, intervention studies have demonstrated that improving coaches' psychosocial knowledge and mental skills enhances functioning and interactions with athletes (Longshore \& Sachs, 2015; Olusoga, Maynard, Butt, \& Hays, 2014), and thereby affects athlete performance outcomes which are a central component of elite sport (Cook \& Fletcher, 2017; McMahon \& Penney, 2013). The purpose of this study, therefore, is to systematically review the research investigating the psychosocial functioning of Olympic coaches and its perceived effect on athlete performance.

\section{Method}

Meta-integration was the method used for this systematic mixed studies review, which involved combining evidence and results from quantitative, qualitative, and mixed method studies to gain a multidimensional and comprehensive understanding of the topic (cf. Frantzen \& Fetters, 2016). This method of conducting a systematic review was deemed the most appropriate because the nature of coaching has lent itself to a diverse range of study designs, therefore prohibiting a meta-analysis or meta-synthesis. Rather, meta-integration is a powerful tool to synthesize data or results from studies with different designs, and summarize all research findings to provide evidence-based recommendations for practice and identify research gaps (Pluye \& Hong, 2014). This systematic review was informed by the Preferred Reporting Items for Systematic Reviews and Meta-Analysis (PRISMA) guidelines (Moher et al., 2015) and followed the recommendations of Van Tulder et al. (2003), Harris, Quatman, Manring, Siston, and Flanigan (2014), and Frantzen and Fetters (2016). There were five steps used for conducting this systematic review: literature search, inclusion criteria, methodological quality assessment, data extraction, and data analysis (Van Tulder et al., 2003). 


\section{Literature Search}

The literature search strategy involved two stages to identify articles relating to psychosocial functioning of Olympic coaches and its perceived effect on athlete performance. First, seven bibliographic databases were searched: SPORTDiscus, PsycINFO, PsycARTICLES, ScienceDirect, Scopus, Web of Knowledge, and Medline. There were no constraints on the year of publication. The search protocol outlined a process which included a search of title, abstracts, and full studies using the following terms: ("athlete," OR “coach," OR "coach-athlete," OR “elite,” OR “effective,” OR “expert,” OR “high performance,”) AND (“Olympic,” OR “sport,” OR "world," OR "world-class"). The search terms were agreed a priori by the author team, and were intentionally broad to minimize the risk of relevant literature being missed (Gough, Thomas, \& Oliver, 2012). The second stage involved hand-searching the reference lists of the studies which met the inclusion criteria (Centre for Reviews \& Dissemination; CRD, 2009).

\section{Inclusion Criteria}

To be included in the review, studies were required to meet the following inclusion criteria: (i) present original empirical data relating to the psychosocial functioning of Olympic coaches; (ii) the entire study population must be explicitly from Olympic sport or must make reference to Olympic sport, and (iii) English language journal articles only. Although only including English language papers potentially leads to a biased sample, there is evidence that such a bias may not influence the results (Morrison et al., 2012).

Sifting of studies was carried out in three stages. The titles were initially screened by the first author for any indication that the study included relevant data. In instances where the title suggested the inclusion of pertinent data, the abstracts were read to establish whether the three inclusion criteria were met, and full texts were then read (see Figure 1). At each stage of 
appraisal, articles were excluded if they did not satisfy the inclusion criteria. For example, studies were excluded if: they did not present original empirical data relating to psychosocial functioning of Olympic coaches (e.g. Chan \& Mallett, 2011); the sample did not consist entirely of Olympic participants (e.g. Lara-Bercial \& Mallett, 2016); or they were not English language journal articles (e.g. Filgueira, 2016).

\section{Methodological Quality Assessment}

To enhance methodological rigor, and in accordance with systematic review guidelines (e.g. Harris et al., 2014; van Tulder et al., 2003) and recent reviews within sport psychology (e.g. Forsdyke, Smith, Jones \& Gledhill, 2016; Gledhill, Harwood, \& Forsdyke, 2017; Howells, Sarkar, \& Fletcher, 2017), a peer-review team was formed to minimize bias and human error. The team included the first author, a senior researcher from the same institution, and a senior researcher from an external institution. Established methods for peer debriefing involve individuals who are either knowledgeable of the topic area and/or methodology supporting the process by providing methodological guidance, and by playing 'devil's advocate' (Spillett, 2003). The search strategy, record screening, and the generation of final themes from the studies was undertaken collaboratively in meetings between the first and second author, with disagreements resolved through a process of constructive debate. Guidance on the process of conducting systematic reviews was provided by the third author via formal and informal meetings with the first author.

The methodological quality of the studies was evaluated using the Mixed Methods Appraisal Tool (MMAT; Pluye, Gagnon, Griffiths, Johnson-Lafleur, 2009; Pluye et al. 2011). This has been recognized as the most reliable and valid tool for appraising mixed methods research (Hong, Gonzalez-Reyes, Pluye, 2018; Pace et al., 2012; Souto et al., 2015), and studies 
that have used the MMAT have reported the consistency of the global 'quality score' between 0.72 and 0.94 (Pace et al., 2012). The tool has recently been utilized in contemporary systematic reviews in sport psychology (Bryan, O’Shea, \& MacIntyre, 2017; Forsdyke et al., 2016; Gledhill et al., 2017; Howells et al., 2017). The MMAT checklist is made up of two screening questions and 19 items for appraising the methodological quality of five categories of research study: (1) qualitative studies, (2) quantitative randomized controlled trials, (3) quantitative non-randomized studies, (4) quantitative descriptive studies, and (5) mixed methods studies. Each of the studies was appraised using the corresponding methodology-domain specific criteria. All items were rated as "yes," "no," or "cannot tell," and one point was given to each yes, and zero points for each no or cannot tell response. These scores produced an overall quality score ranging from 04, and this was converted into a percentage-based score. It is recognized that generating specific scores from critical appraisal tools, including MMAT, is controversial (e.g., Higgins et al., 2019; Hong et al., 2018). The scores, therefore, do not provide an exact metric for study quality, but rather act as a guide to the relative performance of each included study against the MMAT criteria. In addition to calculating a total score, the percentage of studies that met each relevant criteria was calculated, and trends across the studies were explored.

\section{Data Extraction}

Study characteristics, including purpose, participants, sport(s), design, data collection, and the main findings were extracted and presented in Table 1. The findings of each study were extracted verbatim from the text and transferred into the data extraction table.

\section{Data Analysis}

Given the majority (18 of 25, 72 percent) of the included studies used a qualitative methodology, there was a requirement for a narrative approach to the analysis. A convergent 
qualitative meta-integration was therefore used to analyse the data (Frantzen \& Fretters, 2016; Hong, Pluye, Bujold, \& Wassef, 2017). Results from all the included studies were transformed into a qualitative format to present relevant patterns, themes, and concepts (Frantzen \& Fretters, 2016; Pluye \& Hong, 2014). More specifically, the data from the quantitative and mixed methods studies were transformed into qualitative findings by using the text from each study's results section, instead of using the numerical outputs. The data from all of the studies was then synthesized using convergent thematic analysis (CRD, 2009; Hong et al., 2017; Pope, Mays, \& Popay, 2007). Convergent thematic analysis involves the identification of patterns or recurring themes through coding relevant findings from multiple studies to bring together, organize, and describe the findings (Frantzen \& Fretters, 2016; Pope et al., 2007). The first stage involved the process of indwelling (Trumbull, Bonney, \& Grudens, 2005), whereby the first author repeatedly read each study to become fully immersed in the data and inferences. This was followed by coding the data, and then grouping similar codes together to form themes, which were denoted in relation to established psychosocial constructs. For example, Jowett (2003) reported unsuccessful performance outcomes from an athlete whose coach was "trapped in his own preoccupations and personal obligations... and that causes anxiety in itself' (p. 453), and this was categorized as high trait anxiety with a perceived debilitative effect on athlete performance. The relationships within the individual studies were then explored, followed by an examination of the relationships between the different studies.

\section{Results}

The literature search identified 2873 studies which potentially met the inclusion criteria (see Figure 1). All study titles were initially screened for relevance, and following this, 2653 studies were removed. The abstracts of the remaining 220 studies were then evaluated, and 185 
of them did not meet the inclusion criteria. The residual 35 studies were finally subjected to fulltext review, and 10 further studies were excluded. This process resulted in the identification of 25 studies which fully met the inclusion criteria, and these were included in the review. No additional, relevant studies were identified from the reference lists of included studies.

\section{Study Characteristics}

Demographic characteristics. The participants $(\mathrm{N}=1143)$ comprised Olympic coaches $(\mathrm{N}=207)$, Olympic athletes $(\mathrm{N}=925)$, and other (i.e. assistant coach, parents, and Olympic athletes' siblings or significant others; $\mathrm{N}=11)$. The sample sizes ranged from one to $444(M=$ 45.7, and $S D=111.9)$. Six studies provided details relating to the age range of the participants ( 28 to 68 years). Twenty-four studies reported the gender of the participants. In total, 185 (16.2\%) were female, $514(45.0 \%)$ were male, and 444 (38.8\%) were unknown. Twenty-two studies reported the participants' country, which were the United States of America, Norway, United Kingdom, Australia, Brazil, Canada, China, Estonia, France, Greece, Latvia, Hungary, Mexico, Russia, Spain, and Switzerland. The countries that were represented in multiple studies were the United States of America, Norway, United Kingdom, and Australia. Participants represented eight team and 13 individual sports. Five studies included participants from multiple sports, eight studies sampled participants in one sport only, and 12 studies did not report participants' sports.

\section{Quality Appraisal}

Details of the MMAT methodological quality criteria are provided in Table 2, and the resultant appraisal of each study is reported in Table 3. All of the studies were given a methodological quality percentage score using the MMAT criteria and the quality of each included study ranged from $25 \%$ to $100 \%(M=71 \%)$. The 18 qualitative studies ranged from 
$25 \%$ to $100 \%(M=72.2 \%)$, the four mixed methods studies all scored $75 \%(M=75 \%)$, and the three quantitative studies ranged from $50 \%$ to $100 \%(M=66.7 \%)$.

Utilizing the MMAT quality criteria, it was found that few (four of 18, 22 percent) of the qualitative studies reported details about the role of the researcher(s), how the research process was influenced by the researcher(s), or provided information about the researcher(s) epistemological stance. None of the four mixed methods studies reported the limitations associated with the integration of qualitative and quantitative data. Two out of the three quantitative studies did not use validated measures, or report a satisfactory response rate.

\section{Psychosocial Functioning of Olympic Coaches and its Perceived Effect on Athlete}

\section{Performance}

We identified 84 themes, which were further categorized into three main themes. The main themes were labelled according to relevant and established psychosocial constructs, and were termed traits, states, and behaviors that relate to the psychosocial functioning of Olympic coaches. Returning to the literature that has identified psychosocial constructs (Fleeson, 2012), we amended each title to reflect the literature. Thus, we provided connections with established work to reduce confusion regarding terminology. Traits refer to an individual's characteristics that remain relatively stable throughout their lifespan, states relate to characteristics which are situationally-specific and fluctuate from moment to moment, and behaviors refer to overt and observable actions (cf. Fleeson, 2012; Gross, 2015). The convergent thematic analysis identified 18 themes which related to traits, 28 themes which referred to states, and 38 themes which described behaviors. Based on the paper's description of the finding, the themes were then categorized as having a perceived facilitative, debilitative, or non-categorized relationship with athlete performance (see Figure 2). 
Traits. Twenty-two studies presented findings which were interpreted as referring to coaches' traits. Fourteen traits had a perceived facilitative effect on athlete performance, three a perceived debilitative effect, and one a perceived non-categorized effect.

Facilitative traits. Traits that had a perceived positive impact on performance were reported in 19 studies. In terms of the Big Five personality traits of conscientiousness, agreeableness, openness, extraversion, and neuroticism (cf. Costa \& McCrae, 2010), eleven studies identified that Olympic coaches were conscientious (Chroni et al., 2016; Din et al., 2015; Dixon et al., 2012; Gould et al., 1999; Gould et al., 2001; Gould, Guinan, Greenleaf, \& Chung, 2002; Gould, Greenleaf, Chung, \& Guinan, 2002; Gould, Dieffenbach, \& Moffett, 2002; Mallett \& Coulter, 2016; Olusoga et al., 2012; Trzaskoma-Bicsérdy et al., 2007). For example, Din et al. (2015) highlighted that a coach was "so methodical in terms of what we were doing each day and why...everything was so well thought out and planned to the most minute detail" (p. 596). The remaining four of the Big Five traits were only found in a single study: Mallett and Coulter (2016) reported that the coach was "high in agreeableness" (p. 117), "high in openness" (p. 117), “in the average range of extraversion" (p. 117), and "very low neuroticism" (p. 117).

Moving beyond the Big Five, a high task orientation was identified in seven studies (Chroni et al., 2016; Din et al., 2015; Dixon et al., 2012; Lyons et al., 2012; Mallett, 2005; Pensgaard \& Roberts, 2000; Pensgaard \& Roberts, 2002). For example, Chroni et al. (2016) reported a coach stating that "I do not get hung up on results...I am not bothered whether an athlete comes in sixth or tenth or twelfth place...I focus more on their development, and if they have developed, this is very positive for me" (p. 264). Five studies (Din et al., 2015; Dixon et al., 2012; Gould, Guinan, Greenleaf, \& Chung, 2002; Mallett \& Coulter, 2016; Phillippe \& Seiler, 2006) identified a "sense of optimism" (Gould, Dieffenbach, \& Moffett, 2002, p. 193), 
while a "passion for coaching" (Dixon et al., 2012, p. 357) was also detailed in five studies (Chroni et al., 2016; Currie \& Oates-Wilding, 2012; Dixon et al., 2012; Mallett \& Coulter, 2016; Olusoga et al., 2012). Trait emotional intelligence was identified as being facilitative in four studies (Kimiecik \& Gould, 1993; Mallett \& Coulter, 2016; Olusoga et al., 2012; Pensgaard \& Roberts, 2002). Three studies reported high self-esteem amongst coaches (Currie \& OatesWilding, 2012; Din et al., 2015; Olusoga et al., 2012), and trait intelligence was identified in three studies (Chroni et al., 2016; Gould et al., 1999; Seanor et al., 2017). Two studies reported coaches' perfectionism (Chroni et al., 2016; Gould et al., 1999), with Chroni et al. (2016) reporting that a coach perceived their own tendencies as "perfectionist...in their training and organizing their day to day lives and every single detail. There is no space for being lazy or not doing every single thing well" (p. 268). Trait self-control was identified in one study (Olusoga et al., 2012), and finally, one paper reported the coach was "hardy" (Mallett \& Coulter, 2016, p. 117).

Debilitative traits. Four studies reported characteristics that were perceived to be detrimental to performance. Trait anxiety was described in two studies (Greenleaf et al., 2001; Jowett, 2003), and one study described high neuroticism (Greenleaf et al., 2001). Trait pessimism was reported in one study (Gould et al., 1999), with the authors quoting an athlete arguing that, "without [the coaches'] distractions and freak-outs and negativism, I think [the athletes] by ourselves would have medaled" (p. 381).

Non-categorized traits. Six studies identified the trait of ego orientation, which was not consistently reported to have either a perceived positive or negative effect on performance (Chroni et al., 2016; Ge et al., 2016; Gould et al., 1999; Jowett, 2003; Mallett \& Coulter, 2016; Pensgaard \& Roberts, 2000). To illustrate, Jowett (2003) reported perceived unsuccessful athlete 
outcomes from a coach that: "was seemingly consumed with personal ambition and thoughts of maintaining and continuously trying to prove his athlete's competencies" (p. 453). In contrast, Mallett and Coulter (2016) reported perceived successful athlete outcomes from a coach who was: "highly motivated for his athletes to be successful and by association, he will consider himself successful" (p. 118).

States. Twenty-four studies included findings which were interpreted as referring to coaches' states. Eighteen states had a perceived facilitative impact on athlete performance, five a perceived debilitative impact, and five a perceived non-categorized impact.

Facilitative states. Twenty studies identified states that were perceived as having a positive effect on performance. Eight studies suggested that coaches demonstrated otherefficacy through their belief that athletes could successfully execute particular behaviors, which reinforced the athletes' self-confidence (Gould et al., 2001; Gould, Dieffenbach, \& Moffett, 2002; Jowett, 2003; Jowett \& Cockerill, 2003; Kimiecik \& Gould, 1993; Mallett \& Coulter, 2016; Phillippe \& Seiler, 2006; Trzaskoma-Bicsérdy et al., 2007). Gould, Dieffenbach, and Moffett (2002) quoted an athlete expressing that "coach X...just believed in me and that is all it takes" (p. 193). Seven of the included studies reported that coaches had high coaching-efficacy and believed that they had the ability to positively affect athletes' learning and performance (Chroni et al., 2016; Currie \& Oates-Wilding, 2012; Din et al., 2015; Gould et al., 2001; Jowett, 2003; Jowett \& Cockerill, 2003; Mallett, 2005), with Din et al. (2015) quoting an athlete stating that their coach had " $100 \%$ confidence with little or no ego... They have to be very confident in what they are doing" (p. 595-596). The related concept of state self-confidence was reported in three studies (Currie \& Oates-Wilding 2012; Din et al., 2015; Olusoga et al., 2012). Five studies reported state optimism (Din et al., 2015; Dixon et al., 2012; Gould, Guinan, Greenleaf, \& 
Chung, 2002; Mallett \& Coulter, 2016; Phillippe \& Seiler, 2006). Five studies identified coaches' continued learning and pursuit of new knowledge and skills (Chroni et al., 2016; Currie \& Oates-Wilding, 2012; Dixon et al., 2012; Mallet \& Coulter, 2016; Seanor et al., 2017), with Currie and Oates-Wilding (2012) quoting a coach discussing a "commitment to keep learning and improving" (p. 429). Five studies reported high attentional control (Chroni et al., 2016; Gould et al., 1999; Gould, Greenleaf, Chung, \& Guinan, 2002; Gould, Dieffenbach, \& Moffett, 2002; Olusoga et al., 2012), and emotion regulation was identified in five studies (Gould et al., 2001; Gould, Greenleaf, Chung, \& Guinan, 2002; Gould, Dieffenbach, \& Moffett, 2002; Mallett \& Coulter, 2016; Olusoga et al., 2012). Olusoga et al. (2012) quoted a coach stating that they "try not to react when things have gone wrong and an athlete's annoyed... wait for that emotional response to pass, until you can get down and say, "right, ok, let's sit down and talk this through properly" (p.232).

Four studies identified positive attentional biases (Chroni et al., 2016; Din et al., 2015; Dixon et al., 2012; Phillippe \& Seiler, 2006), and state emotional intelligence was identified in four studies (Kimiecik \& Gould, 1993; Mallett \& Coulter, 2016; Olusoga et al., 2012; Pensgaard \& Roberts, 2002). Three studies documented challenge appraisals (Chroni et al., 2016; Din et al., 2015; Dixon et al., 2012). Chroni et al. (2016) quoted a coach explaining that "when the results are not $\mathrm{OK}$, underperformance is a challenge, especially when changes do not bring better performances. This is the good part!” (p. 265). Two studies reported self-awareness (Gould et al., 2001; Olusoga et al., 2012), and self-control was identified in two studies (Gould, Dieffenbach, \& Moffett, 2002; Olusoga et al., 2012). Finally, one study discussed coaches' “resilience" (Currie \& Oates-Wilding, 2012, p. 429). 
In terms of motivational states, six studies identified high task involvement (Chroni et al., 2016; Din et al., 2015; Dixon et al., 2012; Lyons et al., 2012; Mallett, 2005; Pensgaard \& Roberts, 2000; Pensgaard \& Roberts, 2002). This can be exemplified by Pensgaard and Roberts (2002) who reported that the "athletes perceived a high mastery climate" (p. 56). Five studies described coaches' benevolent values (Chroni et al., 2016; Currie \& Oates-Wilding, 2012; Dixon et al., 2012; Gould, Guinan, Greenleaf, \& Chung, 2002; Mallet \& Coulter, 2016). Four studies discussed coaches' intrinsic motivation (Chroni et al., 2016; Kimiecik \& Gould, 1993; Lyons et al., 2012; Sullivan \& Nashman, 1993). Kimiecik and Gould (1993) quoted a coach stating that "we tend to repeat a pleasant experience and avoid an unpleasant experience. Swimming has always been a pleasant experience for me" (p. 352). Three studies (Lyons et al., 2012; Mallett, 2005; Seanor et al., 2017) identified an autonomy supporting motivational style, with Lyons et al. (2012), stating that "the data showed that both the coach and the athletes were primarily oriented towards a self-determined motivational profile and a preference for an autonomy supportive approach to coaching” (p. 367). Finally, one study identified an achievement striving, with Mallett and Coulter (2016) reporting that the coach "strongly seeks to create an achievement-based environment" (p. 118).

Debilitative states. Four studies were identified that discussed states which had a perceived negative impact on performance. State anxiety was reported in two studies (Greenleaf et al., 2001; Jowett, 2003). Greenleaf et al. (2002), for instance, reported one athlete stating that "there was an atmosphere of stress and tension among the staff, coaching staff, and it kind of permeated the whole atmosphere where all the athletes were living" (p. 174). Threat appraisal was reported in two studies (Gould et al., 1999; Gould, Guinan, Greenleaf, \& Chung, 2002), and state pessimism, negative attentional bias, and cognitive rigidity were each reported by one study 
(Gould et al., 1999). With respect to cognitive rigidity, the authors stated that "the athletes and coaches were so "locked" into [their] goals that they had difficulty adjusting to better than expected performance by other teams" (p. 379).

Non-categorized states. Eleven studies reported states for which there was little consistency or consensus regarding their perceived impact on performance. Six studies reported coaches as ego involved (Chroni et al., 2016; Ge et al., 2016; Jowett, 2003; Mallett \& Coulter, 2016; Pensgaard \& Roberts, 2000; Sullivan \& Nashman, 1993), and cognitive flexibility was identified in four studies without a perceived effect on athlete performance (Chroni et al., 2016; Gould et al., 1999; Kimiecik \& Gould, 1993; Phillippe \& Seiler, 2006). Philippe and Seiler (2006) quoted an athlete stating that their coach: "is a flexible person who is open to change. I think his laid-back attitude gives him this flexibility" (p. 166), but it was unclear whether this flexibility had any perceived impact on the athletes' performance. Extrinsic motivation was identified in three studies (Ge et al., 2016; Mallett \& Coulter, 2016; Sullivan \& Nashman, 1993), three studies reported power strivings (Ge et al., 2016; Greenleaf et al., 2001; Mallett \& Coulter, 2016), and finally, an external locus of causality was reported in one study (Currie \& OatesWilding, 2012, p. 428).

Behaviors. All 25 studies reported data which referenced coaches' behaviors. Twentyfive behaviors had a perceived facilitative effect on athlete performance, six a perceived debilitative effect, and seven a perceived non-categorized effect.

Facilitative behaviors. Behaviors that were perceived to have a positive impact on performance were reported in all 25 studies. In terms of behaviors that promoted feelings of affiliation between the coach and athlete, thirteen studies reported that coaches demonstrated understanding and concern (Currie \& Oates-Wilding, 2012; D’Arripe-Longueville et al., 1998; 
Din et al., 2015; Dixon et al., 2012; Ge et al., 2016; Gould, Guinan, Greenleaf, \& Chung, 2002; Jowett, 2003; Jowett \& Cockerill, 2003; Kimiecik \& Gould, 1993; Olusoga et al., 2012; Pensgaard \& Roberts, 2002; Phillippe \& Seiler, 2006; Trzaskoma-Bicsérdy et al., 2007). This was noted by Philippe and Seiler (2006) who reported coaches "provide a sympathetic ear when needed" (p. 165). Eleven studies reported that coaches provided praise and encouragement (D’Arripe-Longueville et al., 1998; Dixon et al., 2012; Gould, Guinan, Greenleaf, \& Chung, 2002; Jowett \& Cockerill, 2003; Kimiecik \& Gould, 1993; Lyons et al., 2012; Mallett \& Coulter, 2016; Olusoga et al., 2012; Pensgaard \& Roberts, 2002; Phillippe \& Seiler, 2006; TrzaskomaBicsérdy et al., 2007). Eight studies identified that coaches demonstrated trustworthy behaviors (Din et al., 2015; Gould et al., 2001; Gould, Guinan, Greenleaf, \& Chung, 2002; Gould, Greenleaf, Chung, \& Guinan, 2002; Greenleaf et al., 2001; Jowett, 2003; Jowett \& Cockerill, 2003; Trzaskoma-Bicsérdy et al., 2007). Seven studies identified that coaches tailored their communication to athletes (Currie \& Oates-Wilding, 2012; Gould et al., 2001; Gould, Greenleaf, Chung, \& Guinan, 2002; Kimiecik \& Gould, 1993; Olusoga et al., 2012; Pensgaard \& Roberts, 2002; Phillippe \& Seiler, 2006), with Olusoga et al. (2012) reporting a coach stating that "it's absolutely about tailoring the communication between athlete and the coach in a form that is mutually acceptable to both parties" (p. 233).

Six studies highlighted coaches displaying confident body language (Din et al., 2015; Gould, Guinan, Greenleaf, \& Chung, 2002; Jowett, 2003; Jowett \& Cockerill, 2003; Olusoga et al., 2012; Trzaskoma-Bicsérdy et al., 2007). Din et al. (2015), for example, quoted an athlete describing their coach "as portraying confidence in the face of adversity" (p. 596). Six studies identified that coaches made fair and decisive decisions (D'Arripe-Longueville et al., 1998; Din et al., 2015; Gould et al., 2001; Gould, Greenleaf, Chung, \& Guinan, 2002; Jowett \& Cockerill, 
2003; Trzaskoma-Bicsérdy et al., 2007), and five studies reported coaches creating enjoyable training sessions (Din et al., 2015; Dixon et al., 2012; Kimiecik \& Gould, 1993; Lyons et al., 2012; Seanor et al., 2017). Three studies described coaches as communicating enthusiasm (Gould et al., 1999; Kimiecik \& Gould, 1993; Mallett \& Coulter, 2016), and two studies highlighted that coaches explicitly reinforced athlete's self-belief (Kimiecik \& Gould, 1993; Mallett and Coulter, 2016). Mallett and Coulter (2016), for example, described the coach prior to the final at the Olympic Games "telling the athlete what they had done to give themselves the opportunity to win" (p. 120).

In terms of behaviors that were aligned with self-determination theory and were autonomy-supporting, eight studies reported that coaches acknowledged the feelings and perspectives of others (Dixon et al., 2012; Ge et al., 2016; Jowett, 2003; Jowett \& Cockerill, 2003; Lyons et al., 2012; Mallett, 2005; Phillippe \& Seiler, 2006; Trzaskoma-Bicsérdy et al., 2007). Ge et al (2016) quoted an athlete stating that "my coach started to ask about my feelings about my injury and even listened to my opinions about techniques... and I think that's one of the reasons I experienced a big performance improvement before the Olympics and won the medal" (p. 5).

Four studies described coaches providing choices to athletes in their training (Lyons et al., 2012; Mallett, 2005; Phillippe \& Seiler, 2006; Seanor et al., 2017). Two studies reported that coaches asked facilitative questions (Mallett, 2005; Seanor et al., 2017), with Seanor et al. (2017) stating that "coaches ask facilitative questions in order to facilitate their development rather than tethering the athlete to the coaches input" (p. 103). Two studies identified coaches providing a rationale for tasks and decision making (Lyons et al., 2012; Mallett, 2005), and one study described the coach providing athletes with opportunities for independent work (Mallett, 2005). 
Regarding behaviors relating to planning, and sport-specific and sport-science knowledge, eleven studies identified that coaches created detailed training programs (Chroni et al., 2016; Din et al., 2015; Ge et al., 2016; Gould et al., 1999; Gould et al., 2001; Gould, Guinan, Greenleaf, \& Chung, 2002; Gould, Greenleaf, Chung, \& Guinan, 2002; Gould, Dieffenbach, \& Moffett, 2002; Greenleaf et al., 2001; Mallett \& Coulter, 2016; Phillippe \& Seiler, 2006). Three studies described the creation of detailed plans for the Olympic Games (Chroni et al., 2016; Gould et al., 1999; Mallett \& Coulter, 2016). Seven studies reported that coaches actively taught psychological skills to athletes (D'Arripe-Longueville et al., 1998; Dixon et al., 2012; Gould et al., 2001; Gould, Guinan, Greenleaf, \& Chung, 2002; Gould, Dieffenbach, \& Moffett, 2002; Greenleaf et al., 2001; Kimiecik \& Gould, 1993), with Gould et al. (2001) stating that the specified coach "developed and implemented a sound physical and mental preparation program" (p. 168). Six studies reported that coaches demonstrated knowledge of the sport (Currie \& Oates-Wilding, 2012; Dixon et al., 2012; Gould et al., 1999; Gould, Greenleaf, Chung, \& Guinan, 2002; Lyons et al., 2012; Phillippe \& Seiler, 2006), and three studies described coaches leading and/or monitoring sport science support (Din et al., 2015; Dixon et al., 2012; Seanor et al., 2017). Dixon et al. (2012) suggested that "whilst the coach leads and monitors that provision of sport science support, [coach's name] recognizes the importance of expertise... and encourages practitioners to use their own initiative" (p. 356).

In terms of feedback, evaluation-focus, and coping behaviors, ten studies discussed the provision of corrective feedback (D’Arripe-Longueville et al., 1998; Din et al., 2015; Dixon et al., 2012; Gould, Guinan, Greenleaf, \& Chung, 2002; Jowett, 2003; Jowett \& Cockerill, 2003; Lyons et al., 2012; Mallett, 2005; Pensgaard \& Roberts, 2002; Phillippe \& Seiler, 2006), and three studies reported that coaches provided positive feedback (Gould, Guinan, Greenleaf, \& 
Chung, 2002; Kimiecik \& Gould, 1993; Lyons et al., 2012). Gould, Dieffenbach, and Moffett (2002), for example, stated that "coaches provided positive and helpful feedback and critiques that helped guide athletes' development as well as provided positive growing environments and opportunities" (p. 193). Eight studies reported that coaches set realistic expectations and goals which served to strengthen motivation (Gould et al., 2001; Gould, Dieffenbach, \& Moffett, 2002; Jowett, 2003; Jowett \& Cockerill, 2003; Kimiecik \& Gould, 1993; Olusoga et al., 2012; Phillippe \& Seiler, 2006; Trzaskoma-Bicsérdy et al., 2007). One study reported that the coach emphasized process goals, with Dixon et al. (2012) highlighting that "maintaining a process focus in a results-driven environment reflects not only persistency, but a high degree of coaching expertize" (p. 357). One study reported that the coaches evaluated athletes on their personal development (Pensgaard \& Roberts, 2000), and finally, two studies highlighted coaches’ utilization of problem-focused coping strategies, such as planning (Chroni et al., 2016; Olusoga et al., 2012).

Debilitative behaviors. Nine studies reported behaviors that had a perceived negative impact on performance. Four studies identified that coaches were unfocused, which became particularly pronounced and debilitating for athletes at the Olympic Games (Gould et al., 1999; Gould et al., 2001; Gould, Dieffenbach, \& Moffett, 2002; Greenleaf et al., 2001). Three studies reported visible stress amongst coaches which caused difficulties at the Olympic Games (Gould et al., 1999; Gould, Dieffenbach, \& Moffett, 2002; Greenleaf et al., 2001), and three studies highlighted coaches displaying uncaring behaviors (D’Arripe-Longueville et al., 1998; Jowett, 2003; Jowett \& Cockerill, 2003). To illustrate, Jowett and Cockerill (2003) quoted an athlete stating that they had worked with a "coach who couldn't care less for you... [He] did not explicitly express an interest in me personally, nor in my training sessions...the worst of all I felt 
I was being used by him” (p. 321). Three studies (D’Arripe-Longueville et al., 1998; Ge et al., 2016; Jowett, 2003) highlighted that coaches ignored athletes' feelings or perspectives. Three studies identified that coaches demonstrated a lack of sport knowledge which reduced the trust required between coach and athlete (Gould et al., 1999; Greenleaf et al., 2001; Jowett \& Cockerill, 2003). Jowett and Cockerill (2003) quoted an athlete stating that "at times I felt that I knew much more than the coach about the sport...I felt that the training plan was not always the best. So there were times where I could sense his weaknesses" (pp. 324-325). Finally, one paper reported coaches setting unrealistic expectations and goals, with Gould, Greenleaf, Chung and Guinan (2002) stating that "athletes indicated that their coach had unrealistic expectations for athletes' performance and felt this negatively affected their performance” (p. 180).

Non-categorized behaviors. Ten studies reported behaviors of which there is little consensus or consistency regarding their perceived effect on performance outcomes. Five studies highlighted that coaches evaluated athletes on their relative standing to others (D'ArripeLongueville et al., 1998; Ge et al., 2016; Jowett, 2003; Pensgaard \& Roberts, 2000; Seanor et al., 2017). The following two quotes provide an example of how this behavior was interpreted as either facilitative or debilitative. Jowett (2003) quoted an athlete stating that "I have come to believe that [my coach] does things just to annoy me, to create problems; for example, he compares me with other athletes in a degrading way" (p. 449), and Seanor et al. (2017) stated that "the degree of difficulty wall has the names and difficulties of every national level routine performed. The wall helps to keep current athletes motivated and focused on their development" (p. 102).

In terms of leaderships style, four studies (D’Arripe-Longueville et al., 1998; Ge et al., 2016; Jowett, 2003; Trzaskoma-Bicsérdy et al., 2007) reported an “authoritarian” (D’Arripe- 
Longueville et al., 1998p. 321) leadership style, and one study identified both "liberal" (Trzaskoma-Bicsérdy et al., 2007, p. 492) and "democratic" (Trzaskoma-Bicsérdy et al., 2007, p. 492) leadership styles. Moving to coping behaviors, three studies highlighted that coaches utilized emotion-focused coping strategies (Gould et al., 2001; Olusoga et al., 2012; Sullivan \& Nashman, 1993). Two studies reported coaches providing negative feedback, which was not consistently perceived as having either a facilitative or debilitative effect on athlete performance (D’Arripe-Longueville et al., 1998; Kimiecik \& Gould, 1993). D’Arripe-Longueviile et al. (1998), for example, stating that the coaches used "aggressive or ironic tones during verbal exchanges, or negative feedback in training or just before competition” (p. 323). Finally, one study reported that coaches created difficulties to build team spirit (D'Arripe-Longueviile et al., 1998).

\section{Discussion}

Using meta-integration techniques, this study systematically reviewed research investigating the psychosocial functioning of Olympic coaches and its perceived effect on athlete performance. The convergent thematic analysis identified three themes from the literature, namely traits, states, and behaviors. The theme of traits refers to the Olympic coaches' cognitive, motivational and affective processes which are stable across time and situation, and states represent the context-specific manifestations of traits. The final tier of coaches' psychosocial attributes relates to their behaviors, which are socially meaningful overt or observable actions.

Olympic coaching research is both multi-paradigmatic and multi-disciplinary, containing an array of related concepts. The multi-disciplinary nature means that many of the concepts originate from different knowledge bases, such as psychology or sociology. Despite the inherent 
strength this brings, the fragmentation hinders the different streams from communicating effectively with each other and impedes the research. This lack of consistent conceptualization across the studies and lack of common language made the findings difficult to synthesize and interpret. There was also a general emphasis on 'bright' characteristics of Olympic coaches that describe their socially desirable attributes (cf. Judge et al., 2009), and this may paint an unrealistic and somewhat simplistic picture of Olympic coaching. Indeed, there has been a recent shift within the related field of organizational leadership towards understanding the full spectrum of leaders' attributes including dark side characteristics and the primarily derailing, although sometimes advantageous, effects of these on organizational outcomes (e.g. Furnham, Trickey, \& Hyde, 2012; Harms \& Spain, 2015; Judge et al., 2009). Dark side characteristics represent an individual's socially undesirable attributes (Hogan \& Hogan, 2001), and it has been suggested that research examining these characteristics would create practically meaningful knowledge within sport (Arnold, Fletcher, \& Hobson, 2018; Cruickshank \& Collins, 2016, 2017; Fletcher \& Arnold, 2011).

\section{Traits}

Eighteen traits were identified across the studies. Traits were the least examined characteristics across the research, which is surprising given the intuitive belief that personality traits predict behavior (Laborde, Allen, Katschak, Mattonet, \& Lachner, 2019; Roberts, Hill, \& Davis, 2017). There was a narrow focus on specific traits and lack of apparent empirical progression beyond these attributes. Conscientiousness was perceived to have a positive relationship with athlete performance because it confers a tendency to be controlled, persistent, and industrious (John, Naumann, \& Soto, 2008; MacCann, Duckworth, \& Roberts, 2009). It was suggested that coaches who are responsible, organized, and willing to work hard are likely to cope well, and even thrive, with the demanding and often relentless requirements of Olympic 
sport. The research also highlighted characteristics of positive, committed, and focused individuals. It is surprising that only Mallett and Coulter (2016) utilized the Big Five theory to understand coaches' personality traits. This contrasts with research from the related field of organizational leadership, where a substantial literature base has been built demonstrating the relationship between the Big Five traits and leadership emergence and effectiveness, with many meta-analyses demonstrating the strength of these relationships (e.g. Judge, Bono, Ilies, \& Gerhardt, 2002; Judge et al., 2009).

\section{States}

Twenty-eight states were highlighted across the literature. Much of the research regarding states has highlighted coaches' other-efficacy and coaching-efficacy. Both of these were perceived to enhance athlete outcomes by improving the coach-athlete relationship and increasing commitment, effort, and perseverance when faced with difficulty. There was a noticeable trend towards identifying whether coaches were task- or ego-involved, which reflects the importance that the wider sport psychology literature has placed upon these constructs (e.g. Harwood, Keegan, Smith, \& Raine, 2015). As ego-involvement was perceived to have a noncategorized effect on performance outcomes, further work is required to explore this construct and fully understand the effects on Olympic-level athletes. Few of the studies examined the context and the situational-cues which activated the coach's states. This is an important omission from the literature as there may be certain environmental factors which trigger specific states, and this knowledge is required if researchers pursue intervention studies. Taken together, many of the states identified in the literature were replicated across a number of studies, thus progressing knowledge and providing a platform for future research.

\section{Behaviors}


Thirty-eight behaviors were identified across the studies, and research examining coach behaviors represented the largest body of work across the studies. There was a significant trend towards identifying the behaviors which underpinned the coach-athlete relationship, particularly coaches' demonstrating understanding and concern towards athletes, and providing praise and encouragement. It was suggested that coaches' expressions of warmth were perceived as signals of affiliation, promoting psychological safety and enhancing athletes' willingness to openly share information, which facilitated performance outcomes. There was a trend towards investigating coaches use of autonomy supporting behaviors, which were suggested to facilitate Olympic athlete's motivation, performance, and well-being. However, there was limited discussion of the context in which specific coaching behaviors occurred. It is important that future research gives more space to explaining and examining the context so that the findings can be, where appropriate, generalized or transferred. It was surprising that none of the studies used systematic observation of coaches given that these methods represent one of the most common forms of research within coaching as a whole (Cope, Partington, \& Harvey, 2017).

\section{Methods}

The vast majority of the studies utilized a qualitative design, with semi-structured interviews being the most used data collection method. Although this methodology provides many insights and nuances, there would be a benefit in more studies employing quantitative or mixed methods designs to create testable hypotheses and measure theoretically relevant constructs with validated instruments. The studies examined psychosocial functioning of Olympic coaches from both athlete and coach perspectives. This is encouraging as coaches selfreported perceptions of their own characteristics and performance provides an insight into their internal world, and athlete observer-reports represent an additional and important source of 
information about coaches behaviors and reputations. Surprisingly, there was limited use of longitudinal studies, and greater use of this design would facilitate an understanding of the relationship between coaches' characteristics and performance outcomes. There was also a lack of research which used comparative designs. This is an important point for future researchers to address so that a greater understanding of which factors may discriminate between more or less successful Olympic coaches can begin to be developed. Finally, the majority of studies provided a limited description of coaches' characteristics, such as the sport coached, their age, or years of coaching experience. This limits the ability to determine whether coaching experience has a facilitative effect on athlete performance, and whether this may be more or less influential in specific sports. It also restricts the ability of future studies to replicate these findings. Recently, the need to replicate studies has attracted considerable attention within the field of psychology (Maxwell, Lau, \& Howard, 2015), and it is important that future research within coaching reports the participant characteristics (whilst maintaining anonymity) so that we can begin to understand whether patterns within the data are just noise or whether they reflect a deeper meaning.

\section{Limitations of This Review}

This was the first review to systematically synthesize and evaluate the research relating to psychosocial functioning of Olympic coaches, and allows a growing body of literature to become easily accessible. It has provided original information regarding research trends which may not be apparent from any individual study, and provides inferences and conclusions based on the collation of these findings. However, there are some limitations which require consideration when interpreting the results. Although this review highlights the frequency that studies have provided the individual finings, this does not imply meaning. The number of studies per finding is not meant to indicate the relative importance of any trait, state, or behavior, and researchers 
could adopt methods that focus on exploring the meaning behind the numbers. Further, the focus of the studies was rarely to specifically investigate coaches' psychosocial functioning through the lens of established constructs or theories. This meant that some of the results were translated into psychosocial terminology, for example findings which highlighted a coach's consistent worries across contexts were interpreted as trait anxiety. This review did not employ a comparison group as the purpose was to examine the Olympic coaching literature, and so it is unclear whether the psychosocial characteristics outlined in this review are different from the characteristics exhibited by coaches from other levels of sport. It would be interesting to understand whether certain characteristics are particularly salient at certain standards of competition, as each level of sport has its own set of internal and external pressures. The review was limited to English language journal articles, meaning that information from non-English language studies may have been missed, and therefore these findings may not reflect the global body of coaching research.

\section{Future Research Directions}

There are a number of avenues that would benefit from further exploration. Personality traits do not exist within a vacuum, instead they function collectively with other personality subsystems to enable the expression of psychological individuality (Coulter, Mallett, Singer, \& Gucciardi, 2016; Roberts \& Woodman, 2017). Rather than examining traits in isolation, multivariate designs would be a useful next step towards understanding the role of theoretically relevant constructs in Olympic coaching. This research would not only facilitate an understanding of the relative importance of each trait, but also how they interact together to produce behavioral and performance outcomes. The complexity of coaching lends itself to diverse study designs, and using both quantitative and qualitative methods would enrich our 
understanding of psychosocial functioning of Olympic coaches. Indeed, different qualitative methodologies, such as ethnographic or narrative research, would help to further develop our understanding of who these coaches are, what they do, why they do it, and what drives their behavior (Denzin \& Lincoln, 2011; Sparkes \& Smith, 2014). It is also important that future research examines whether there are any psychosocial factors which discriminate between coaches whose athletes have produced different performance outcomes in Olympic competition. There may, for example, be discriminating characteristics between coaches who have coached athletes to win Olympic gold medals and those whose athletes have reached the Olympic Games but not won a gold medal, or between coaches whose athletes have achieved an Olympic podium or non-podium finish. Studies using these comparator groups would then be able to develop an understanding of the unique factors which may discriminate these gold-medal winning or podium Olympic coaches, rather than the existing research which compares all Olympic coaches as a single cohort with non-Olympic coaches. This would develop the empirical research base and help to determine the factors which may be advantageous towards coaching an athlete to win an Olympic gold, silver or bronze medal.

\section{Implications for Practice}

Several applied implications arise from the findings. The results provide coach educators, National Governing Bodies, and applied sport psychologists with an outline of the characteristics which may be important for Olympic coaches to develop. Applied sport psychologists often monitor individuals across training and competitions in order to strengthen their existing facilitative skillsets and identify maladaptive patterns which may require intervention. Identifying the characteristics which are likely to have a debilitative effect on coaches' performance is important for applied sport psychologists, and recent research has 
demonstrated that many characteristics, including traits, are modifiable through evidence-based interventions (see Roberts \& Woodman, 2017). Studies within this review emphasized the importance of coaches' conscientiousness, coaching-efficacy, and the role of the coach-athlete relationship for positive athlete performance outcomes. It is important that coach educators and National Governing Bodies integrate these findings into their coach development programs to enhance coaches' practice.

\section{Concluding Remarks}

This is the first synthesis of all the relevant, published evidence on psychosocial functioning of Olympic coaches and its perceived effect on athlete performance. It highlights what the research has found to be facilitative, debilitative, or non-categorized, and this can be used proactively by relevant stakeholders. The identified limitations of the existing research provide directions for future work to further enrich our understanding of Olympic coaching, and so enhance coach development programs and performance outcomes. 


\section{References}

References marked with an asterisk indicate studies included in the systematic review.

Abraham, A., Collins, D., \& Martindale, R. (2006). The coaching schematic: Validation through expert coach consensus. Journal of Sports Sciences, 24, 549-564.

doi: $10.1080 / 02640410500189173$

Amorose, A. J. (2007). Coaching effectiveness: Exploring the relationship between coaching behavior and motivation from a self-determination theory perspective. In M. Hagger \& N. L. D. Chatzisarantis (Eds.), Intrinsic motivation and self-determination in exercise and sport (pp. 209-228). Champaign, IL: Human Kinetics.

Arnold, R., Fletcher, D., \& Hobson, J. A. (2018). Performance leadership and management in elite sport: A black and white issue or different shades of grey? Journal of Sport Management, 32, 452-463. doi:10.1123/jsm.2017-0296.

Bryan, C., O’Shea, D., \& MacIntyre, T. (2017). Stressing the relevance of resilience: a systematic review of resilience across the domains of sport and work. International Review of Sport and Exercise Psychology, 1-41. doi:10.1080/1750984X.2017.1381140

Centre for Reviews and Dissemination. (2009). Systematic reviews: CRD's guidance for undertaking reviews in health care. York, UK: University of York.

Chan, J. T. \& Mallett, C. J. (2011). The value of emotional intelligence for high performance coaching. International Journal of Sports Science and Coaching, 6, 315-328. doi:10.1260\%2F1747-9541.6.3.351

Chelladurai, P. (2007). Leadership in sports. In G.Tenenbaum \& R. C. Eklund (Eds.). Handbook of sport psychology (pp. 113-135). Hoboken, NJ: Wiley. 
*Chroni, S. A., Abrahamsen, F., \& Hemmestad, L. (2016). To be the eye within the storm, I am challenged not stressed. Journal of Applied Sport Psychology, 28, 257-273. doi:10.1080/10413200.2015.1113449

Cogan, K. D. (2019). Coaching Olympic athletes with sport psychology. Consulting Psychology Journal: Practice and Research, 71, 86-96. doi:10.1037/cpb0000129

Cook, G. M., \& Fletcher, D. (2017). Sport psychology in an Olympic swimming team: Perceptions of the management and coaches. Professional Psychology: Research and Practice, 48, 343-351. doi:10.1037/pro0000142

Cope, E., Partington, M., \& Harvey, S. (2017). A review of the use of a systematic observation method in coaching research between 1997 and 2016. Journal of Sports Sciences, 35, 2042-2050. doi:10.1080/02640414.2016.1252463

Costa, P. T., \& McCrae, R. R. (2010). Bridging the gap with the five-factor model. Personality Disorders: Theory, Research, and Treatment, 1, 127-130. doi:10.1037/a0020264

Côté, J., \& Gilbert, W. (2009). An integrative definition of coaching effectiveness and expertise. International Journal of Sports Science and Coaching, 4, 307-323. doi:10.1260\%2F174795409789623892

Coulter, T. J., Mallett, C. J., Singer, J. A., \& Gucciardi, D. F. (2016). Personality in sport and exercise psychology: Integrating a whole person perspective. International Journal of Sport and Exercise Psychology, 14, 23-41. doi:10.1080/1612197X.2015.1016085

Cruickshank, A., \& Collins, D. (2016). Advancing leadership in sport: Time to take off the blinkers? Sports Medicine, 49, 1199-204. doi:10.1007/s40279-016-0513-1. 
Cruickshank, A., \& Collins, D. (2017). Response to Mills and Boardley: “Advancing leadership in sport: Time to 'actually' take off the blinkers?” Sports Medicine, 47, 571-574. doi:10.1007/s40279-016-0662-2

*Currie, J. L., \& Oates-Wilding, S. (2012). Reflections on a dream: Towards an understanding of factors Olympic coaches attribute to their success. Reflective Practice, 13, 425-438. Retrieved from https://www.tandfonline.com/loi/crep20

Cushion, C. (2007). Modelling the complexity of the coaching process. International Journal of Sports Science and Coaching, 2, 395-401. doi:10.1260\%2F174795407783359650

Cushion, C. (2010). Coach behaviour. In Lyle, J and Cushion, C (Eds.), Sports coaching professionalization and practice (pp. 181-182). Edinburgh, UK: Churchill Livingston.

*D’Arripe-Longueville, F., Fournier, J. F., \& Dubois, A. (1998). The perceived effectiveness of interactions between expert French judo coaches and elite female athletes. The Sport Psychologist, 12, 317-332. doi:10.1123/tsp.12.3.317

Denzin, N., \& Lincoln, Y. (2011). Introduction: The discipline and practice of 10 qualitative research. In N. Denzin, \& Y. Lincoln (Eds.), Handbook of qualitative research (pp. 119). London, UK: Sage.

*Din, C., Paskevich, D., Gabriele, T., \& Werthner, P. (2015). Olympic medal-winning leadership. International Journal of Sports Science and Coaching, 10, 589-604. doi:10.1260\%2F 1747-9541.10.4.589

*Dixon, M., Lee, S., \& Ghaye, T. (2012). Coaching for performance: reflections of Olympic diving coach, Andy Banks. Reflective Practice, 13, 355-358. Retrieved from https://www.tandfonline.com/loi/crep20 
Evans, M.B., McGuckin, M., Gainforth, H.L., Bruner, M.W., \& Côté, J. (2015). Coach development programmes to improve interpersonal coach behaviours: A systematic review using the re-aim framework. British Journal of Sports Medicine, 49, 871-877. doi:10.1136/bjsports-2015-094634.

Filgueira, P. (2016). Perception of high performance track and field coaches: Characterization of their multifaceted profile. RETOS-Neuvas Tendencias en Educacion Fisica, Deporte y Recreacion, 29, 42-47. Retrieved from https://recyt.fecyt.es/index.php/retos/index

Fleeson, W. (2012). Perspectives on the person: Rapid growth and opportunities for integration. In K. Deaux \& M. Snyder (Eds.), Oxford library of psychology. The Oxford handbook of personality and social psychology (pp. 33-63). New York, NY: Oxford University Press.

Fletcher, D., \& Arnold, R. (2011). A qualitative study of performance leadership and management in elite sport. Journal of Applied Sport Psychology, 23, 223-242. doi:10.1080/10413200.2011.559184

Fletcher, D., \& Sarkar, M. (2012). A grounded theory of psychological resilience in Olympic champions. Psychology of Sport and Exercise, 13, 669-678. doi:10.1016/j.psychsport.2012.04.007

Fletcher, D., \& Scott, M. (2010). Psychological stress in sports coaches: A review of concepts, research, and practice. Journal of Sports Sciences, 28, 127-137. doi:10.1080/02640410903406208

Forsdyke, D., Smith, A., Jones, M., \& Gledhill, A. (2016). Psychosocial factors associated with outcomes of sports injury rehabilitation in competitive athletes: A mixed studies systematic review. British Journal of Sports Medicine, 50, 137-144. doi:10.1136/bjsports2015-094850 
Frantzen, K. K., \& Fetters, M. D. (2016). Meta-integration for synthesizing data in a systematic mixed studies review: Insights from research on autism spectrum disorder. Quality and Quantity, 50, 2251-2277. doi:10.1007/s11135-015-0261-6

Furnham, A., Trickey, G., \& Hyde, G. (2012). Bright aspects to dark side traits: Dark side traits associated with work success. Personality and Individual Differences, 52, 908-913. doi:10.1016/j.paid.2012.01.025

*Ge, Y., Schinke, R., Dong, D., Lu, C., Si, G., \& Oghene, O. (2016). Working with Chinese Olympic athletes in their national sport system: From the conceptual to a proposed research-practice integration. International Journal of Sport and Exercise Psychology, 14, 1-13. doi:10.1080/1612197X.2016.1164227

Gledhill, A., Harwood, C., \& Forsdyke, D. (2017). Psychosocial factors associated with talent development in football: A systematic review. Psychology of Sport and Exercise, 31, 93112. doi:10.1016/j.psychsport.2017.04.002

Gough, D., Thomas, J., \& Oliver, S. (2012). Clarifying differences between review designs and methods. Systematic Reviews, 28, 1-8. doi:10.1186/2046-4053-1-28

*Gould, D., Dieffenbach, K., \& Moffett, A. (2002). Psychological characteristics and their development in Olympic champions. Journal of Applied Sport Psychology, 14, 172-204. doi:10.1080/10413200290103482

*Gould, D., Greenleaf, C., Guinan, D., Dieffenbach, K., \& McCann, S. (2001). Pursuing performance excellence: Lessons learned from Olympic athletes and coaches. Journal of Excellence, 4, 21-43. Retrieved from http://www.zoneofexcellence.ca 
*Gould, D., Greenleaf, C., Chung, Y., \& Guinan, D. (2002). A survey of US Atlanta and Nagano Olympians: Variables perceived to influence performance. Research Quarterly for Exercise and Sport, 73, 175-186. doi:10.1080/02701367.2002.10609006

*Gould, D., Guinan, D., Greenleaf, C., \& Chung, Y. (2002). A survey of US Olympic coaches: Variables perceived to have influenced athlete performances and coach effectiveness. The Sport Psychologist, 16, 229-250. doi:10.1123/tsp.16.3.229

*Gould, D., Guinan, D., Greenleaf, C., Medbery, R., \& Peterson, K. (1999). Factors affecting Olympic performance: Perceptions of athletes and coaches from more and less successful teams. The Sport Psychologist, 13, 371-394. doi:10.1123/tsp.13.4.371

Gould, D., \& Maynard, I. (2009). Psychological preparation for the Olympic Games. Journal of Sports Sciences, 27, 1393-1408. doi:10.1080/02640410903081845

*Greenleaf, C., Gould, D., \& Dieffenbach, K. (2001). Factors influencing Olympic performance: Interviews with Atlanta and Negano US Olympians. Journal of Applied Sport Psychology, 13, 154-184. doi:10.1080/104132001753149874

Grey-Thompson, T. (2017). Duty of care in sport. Independent report to the government. Retrieved from https://www.gov.uk/government/publications/duty-of-care-in-sportreview

Gross, R. (2015). Psychology: The science of mind and behaviour. London, UK: Hodder and Stoughton Educational.

Haberl, P., \& Peterson, K. (2006). Olympic-size ethical dilemmas: Issues and challenges for sport psychology consultants on the road and at the Olympic Games. Ethics and Behavior, 16, 25-40. doi:10.1207/s15327019eb1601_4 
Harms, P. D., \& Spain, S. M. (2015). Beyond the bright side: Dark personality at work. Applied Psychology, 64, 15-24. doi:10.1111/apps. 12042

Harris, J. D., Quatman, C. E., Manring, M. M., Siston, R. A., \& Flanigan, D. C. (2014). How to write a systematic review. The American Journal of Sports Medicine, 42, 2761-2768. doi:10.1177/0363546513497567

Harwood, C. G., Keegan, R. J., Smith, J. M. J., \& Raine, A. S. (2015). A systematic review of the intrapersonal correlates of motivational climate perceptions in sport and physical activity. Psychology of Sport and Exercise, 18, 9-25.

Higgins, J. P. T, Thomas, J., Chandler, J., Cumpston, M., Li, T., Page, M. J., \& Welch, V. A. (2019). Cochrane Handbook for Systematic Reviews of Interventions. Chichester, UK: John Wiley \& Sons.

Hogan, R., \& Hogan, J. (2001). Assessing leadership: A view from the dark side. International Journal of Selection and Assessment, 9, 40-51. doi:10.1111/1468-2389.00162

Hong, Q. N., Gonzalez-Reyes, A., \& Pluye, P. (2018). Improving the usefulness of a tool for appraising the quality of qualitative, quantitative and mixed methods studies, the Mixed Methods Appraisal Tool (MMAT). Journal of Evaluation in Clinical Practice, 24, 459467. doi:10.1111/jep. 12884

Hong, Q. N., Pluye, P., Bujold, M., \& Wassef, M. (2017). Convergent and sequential synthesis designs: Implications for conducting and reporting systematic reviews of qualitative and quantitative evidence. Systematic Reviews, 6, 1-14. doi:10.1186\%2Fs13643-017-0454-2

Hong, Q. N., Pluye, P., Fàbregues, S., Bartlett, G., Boardman, F., Cargo, M., ... \& Vedel, I. (2018). Mixed Methods Appraisal Tool (MMAT), version 2018. Retrieved from 
http://mixedmethodsappraisaltoolpublic.pbworks.com/w/file/fetch/127916259/MMAT_2 018_criteria-manual_2018-08-01_ENG.pdf

Horn, T. S. (2008). Coaching effectiveness in the sport domain. In T. S. Horn (Eds.), Advances in sport psychology (pp. 239-267). Champaign, IL: Human Kinetics.

Howells, K., Sarkar, M., \& Fletcher, D. (2017). Can athletes benefit from difficulty? A systematic review of growth following adversity in competitive sport. Progress in Brain Research, 234, 117-159. doi:10.1016/bs.pbr.2017.06.002

International Council for Coaching Excellence. (2013). International sport coaching framework (Vol. 1.2). Champaign, IL: Human Kinetics.

John, O. P., Naumann, L. P., \& Soto, C. J. (2008). Paradigm shift to the integrative Big Five trait taxonomy: History, measurement, and conceptual issues. In O. P. John, R. W. Robins, \& L. A. Pervin (Eds.), Handbook of personality: Theory and research (pp. 114-158). New York, NY: Guilford Press.

Jones, R. L., \& Kingston, K. (2013). An introduction to sports coaching: connecting theory to practice. London, UK: Routledge.

*Jowett, S. (2003). When the "honeymoon" is over: A case study of a coach-athlete dyad in crisis. The Sport Psychologist, 17, 444-460. doi:10.1123/tsp.17.4.444

*Jowett, S., \& Cockerill, I. M. (2003). Olympic medallists' perspective of the athlete-coach relationship. Psychology of Sport and Exercise, 4, 313-331. doi:10.1016/S14690292(02)00011-0.

Jowett, S., \& Meek, G. A. (2000). The coach-athlete relationship in married couples: An exploratory content analysis. The Sport Psychologist, 14, 157-175. doi:10.1123/tsp.14.2.157 
Jowett, S., \& Shanmugam, V. (2016). Relational coaching in sport: Its psychological underpinnings and practical effectiveness. In R. Schinke, K. R. McGannon, B. Smith (Eds.), Routledge international handbook of sport psychology (pp. 471-485). New York, NY: Routledge.

Judge, T. A., Bono, J. E., Ilies, R., \& Gerhardt, M. W. (2002). Personality and leadership: A qualitative and quantitative review. Journal of Applied Psychology, 87, 765-780. doi:10.1037//0021-9010.87.4.765

Judge, T. A., Piccolo, R. F., \& Kosalka, T. (2009). The bright and dark sides of leader traits: A review and theoretical extension of the leader trait paradigm. The Leadership Quarterly, 20, 855-875. doi:10.1016/j.leaqua.2009.09.004

*Kimiecik, J., \& Gould, D. (1987). Coaching psychology: The case of James “Doc” Counsilman. The Sport Psychologist, 1, 350-358. doi:10.1123/tsp.1.4.350

Laborde, S., Allen, M. S., Katschak, K., Mattonet, K., \& Lachner, N. (2019). Trait personality in sport and exercise psychology: A mapping review and research agenda. International Journal of Sport and Exercise Psychology. Advance online publication. doi:10.1080/1612197X.2019.1570536

Langan, E., Blake, C., \& Lonsdale, C. (2013). Systematic review of the effectiveness of interpersonal coach education interventions on athlete outcomes. Psychology of Sport and Exercise, 14, 37-49. doi:10.1016/j.psychsport.2012.06.007

Lara-Bercial, S., \& Mallett, C. J. (2016). The practices and developmental pathways of professional and Olympic serial winning coaches. International Sport Coaching Journal, 3, 221-239. doi:10.1123/iscj.2016-0083 
Lefebvre, J. S., Evans, M. B., Turnnidge, J., Gainforth, H. L., \& Côté, J. (2016). Describing and classifying coach development programmes: A synthesis of empirical research and applied practice. International Journal of Sports Science and Coaching, 11, 887-899. doi:10.1177/1747954116676116

Longshore, K., \& Sachs, M. (2015). Mindfulness training for coaches: A mixed-method exploratory study. Journal of Clinical Sport Psychology, 9, 116-137. doi:10.1123/jcsp.2014-0038

Lyle, J. (2002). Sports coaching concepts: A framework for coaches' behavior. New York, NY: Routledge.

Lyle, J., \& Cushion, C. (2016). Sport coaching concepts: A framework for coaching practice. London, UK: Routledge.

*Lyons, M., Rynne, S. B., \& Mallett, C. J. (2012). Reflection and the art of coaching: Fostering high-performance in Olympic Ski Cross. Reflective Practice, 13, 359-372. Retrieved from https://www.tandfonline.com/loi/crep20

MacCann, C., Duckworth, A. L., \& Roberts, R. D. (2009). Empirical identification of the major facets of conscientiousness. Learning and Individual Differences, 19, 451-458. doi:10.1016/j.lindif.2009.03.007

Maclean, J., \& Lorimer, R. (2016). Are coach education programmes the most effective method for coach development? International Journal of Coaching Science, 10, 71-88. doi:10.13140/RG.2.2.15601.28003

Mageau, G. A., \& Vallerand, R. J. (2003). The coach-athlete relationship: A motivational model. Journal of Sports Sciences, 21, 883-904. doi:10.1080/0264041031000140374 
*Mallett, C. J. (2005). Self-determination theory: A case study of evidence-based coaching. The Sport Psychologist, 19, 417-429. doi:10.1123/tsp.19.4.417

*Mallett, C. J., \& Coulter, T. J. (2016). The anatomy of a successful Olympic coach: Actor, agent, and author. International Sport Coaching Journal, 3, 113-127. doi:10.1123/iscj.2015-0069

Mallett, C. J., \& Lara-Bercial, S. (2016). Serial winning coaches: People, vision, and environment. In M. Raab, P. Wylleman, R. Seiler, A-M. Elbe, \& A. Hatzigeorgiadis (Eds.) Sport and exercise psychology research: From theory to practice (pp. 289-322). London, UK: Academic Press.

Maxwell, S. E., Lau, M. Y., \& Howard, G. S. (2015). Is psychology suffering from a replication crisis? What does "failure to replicate" really mean? American Psychologist, 70, 487-498. doi:10.1037/a0039400

McCarthy, P., \& Giges, B. (2016). Helping coaches meet their psychological needs. In R. Thelwell, C. Harwood, \& I. Greenlees (Eds.), The psychology of sports coaching (pp. 113-125). London, UK Routledge.

McMahon, J., \& Penney, D. (2013). Body pedagogies, coaching and culture: three Australian swimmers' lived experiences. Physical Education and Sport Pedagogy, 18, 317-335. doi:10.1080/17408989.2012.666786

Merriam-Webster. (2016). The Merriam-Webster Dictionary. Springfield, MA: MerriamWebster.

Moher, D., Shamseer, L., Clarke, M., Ghersi, D., Liberati, A., Petticrew, M., ... \& Stewart, L. A. (2015). Preferred reporting items for systematic review and meta-analysis protocols (PRISMA-P) 2015 statement. Systematic Reviews, 4, 1-9. doi:10.1186/2046-4053-4-1 
Morrison, A., Polisena, J., Husereau, D., Moulton, K., Clark, M., Fiander, M., ... \& Rabb, D. (2012). The effect of English-language restriction on systematic review-based metaanalyses: A systematic review of empirical studies. International Journal of Technology Assessment in Health Care, 28, 138-144. doi:10.1017/s0266462312000086.

Olusoga, P., Maynard, I., Butt, J., \& Hays, K. (2014). Coaching under pressure: mental skills training for sports coaches. Sport and Exercise Psychology Review, 10, 31-44. Retrieved from https://www.bps.org.uk/publications/sport-and-exercise-psychology-review

*Olusoga, P., Maynard, I., Hays, K., \& Butt, J. (2012). Coaching under pressure: A study of Olympic coaches. Journal of Sports Sciences, 30, 229-239. doi:10.1080/02640414.2011.639384

Pace, R., Pluye, P., Bartlett, G., Macaulay, A. C., Salsberg, J., Jagosh, J., \& Seller, R. (2012). Testing the reliability and efficiency of the pilot Mixed Methods Appraisal Tool (MMAT) for systematic mixed studies review. International Journal of Nursing Studies, 49, 47-53. doi:10.1016/j.ijnurstu.2011.07.002

*Pensgaard, A. M., \& Roberts, G. C. (2000). The relationship between motivational climate, perceived ability and sources of distress among elite athletes. Journal of Sports Sciences, 18, 191-200. doi:10.1080/026404100365090

*Pensgaard, A. M., \& Roberts, G. C. (2002). Elite athletes' experiences of the motivational climate: The coach matters. Scandinavian Journal of Medicine and Science in Sports, 12, 54-59. doi:10.1034/j.1600-0838.2002.120110.x

*Philippe, R. A., \& Seiler, R. (2006). Closeness, co-orientation and complementarity in coachathlete relationship: What male swimmers say about their male coaches. Psychology of Sport and Exercise, 7, 159-171. doi:10.1016/jpsychsport.2005.08.004. 
Pluye, P., Gagnon, M. P., Griffiths, F., \& Johnson-Lafleur, J. (2009). A scoring system for appraising mixed methods research, and concomitantly appraising qualitative, quantitative and mixed methods primary studies in mixed studies reviews. International Journal of Nursing Studies, 46, 529-546. doi:10.1016/j.ijnurstu.2009.01.009

Pluye, P., \& Hong, Q. N. (2014). Combining the power of stories and the power of numbers: Mixed methods research and mixed studies reviews. Annual Review of Public Health, 35, 29-45. doi:10.1146/annurev-publhealth-032013-182440

Pluye, P., Robert, E., Cargo, M., Bartlett, G., O’Cathain, A., Griffiths, F., ... \& Rousseau, M. C. (2011). Proposal: A mixed methods appraisal tool for systematic mixed studies reviews. Retrieved from http://mixedmethodsappraisaltoolpublic.pbworks.com.

Pope, C., Mays, N., \& Popay, J. (2007). Synthesising qualitative and quantitative health evidence: A guide to methods: A guide to methods. Berkshire, UK: Open University Press.

Rees, T., Hardy, L., Güllich, A., Abernethy, B., Côté, J., Woodman, T., ... \& Warr, C. (2016). The great British medalists project: A review of current knowledge on the development of the world's best sporting talent. Sports Medicine, 46, 1041-1058. doi:10.1007/s40279016-0476-2

Roberts, B. W., Hill, P. L., \& Davis, J. P. (2017). How to change conscientiousness: The sociogenomic trait intervention model. Personality Disorders: Theory, Research, and Treatment, 8, 199-205. doi:10.1037/per0000242

Roberts, G. C., Treasure, D. C., \& Balague, G. (1998). Achievement goals in sport: The development and validation of the Perception of Success Questionnaire. Journal of Sports Sciences, 16, 337-347. doi:10.1080/02640419808559362 
Roberts, R., \& Woodman, T. (2017). Personality and performance: Moving beyond the Big 5. Current Opinion in Psychology, 16, 104-108. doi:10.1016/j.copsyc.2017.03.033

Rynne, S. B., Mallett, C. J., \& Rabjohns, M. W. O. (2016). High performance coaching: demands and development. In R. Thelwell, C. Harwood, \& I. Greenlees (Eds.), The psychology of sports coaching: Research and practice (pp. 114-126). Abingdon, UK: Routledge.

*Seanor, M., Schinke, R. J., Stambulova, N. B., Ross, D., \& Kpazai, G. (2017). Cultivating Olympic champions: A trampoline development environment from grass roots to podium. Journal of Sport Psychology in Action, 8, 96-108. doi:10.1080/21520704.2017.1327908

Smith, R. E., Smoll, F. L., \& Cumming, S. P. (2007). Effects of a motivational climate intervention for coaches on young athletes' sport performance anxiety. Journal of Sport and Exercise Psychology, 29, 39-59. doi:10.1123/jsep.29.1.39

Souto, R. Q., Khanassov, V., Hong, Q. N., Bush, P. L., Vedel, I., \& Pluye, P. (2015). Systematic mixed studies reviews: Updating results on the reliability and efficiency of the mixed methods appraisal tool. International Journal of Nursing Studies, 52, 500-501. doi:10.1016/j.ijnurstu.2014.08.010

Sparkes, A. C., \& Smith, B. (2014). Qualitative research methods in sport, exercise and health: From process to product. Abingdon, UK: Routledge.

Spillett, M. A. (2003). Peer debriefing: Who, what, when, why, how. Academic Exchange Quarterly, 7, 36-40. Retrieved from http://rapidintellect.com/AEQweb/

*Sullivan, P. A., \& Nashman, H. W. (1993). The 1992 United States Olympic Team sport coaches: Satisfactions and concerns. Applied Research in Coaching and Athletics 
Annual, 8, 1-14. Retrieved from

https://www.americanpresspublishers.com/ARCAAContents 1993.html

Thelwell, R. C., Wagstaff, C. R., Rayner, A., Chapman, M., \& Barker, J. (2017). Exploring athletes' perceptions of coach stress in elite sport environments. Journal of Sports Sciences, 35, 44-55. doi:10.1080/02640414.2016.1154979

Trudel, P., \& Gilbert, W. D. (2006). Coaching and coach education. In D. Kirk, M. O’Sullivan, \& D. McDonald (Eds.), Handbook of physical education (pp. 516-539). London, UK: Sage.

Trumbull, D. J., Bonney, R., \& Grudens, N. (2005). Developing materials to promote inquiry: Lessons learned. Science Education, 89, 879-900. doi:10.1002/sce.20081

*Trzaskoma-Bicsérdy, G., Bognár, J., Révész, L., \& Géczi, G. (2007). The coach-athlete relationship in successful Hungarian individual sports. International Journal of Sports Science and Coaching, 2, 485-495. doi:10.1260\%2F174795407783359759

Van Tulder, M., Furlan, A., Bombardier, C., Bouter, L., \& Editorial Board of the Cochrane Collaboration Back Review Group. (2003). Updated method guidelines for systematic reviews in the cochrane collaboration back review group. Spine, 28, 1290-1299. doi:10.1097/01.BRS.0000065484.95996.AF

Vealey, R. S., Armstrong, L., Comar, W., \& Greenleaf, C. A. (1998). Influence of perceived coaching behaviors on burnout and competitive anxiety in female college athletes. Journal of Applied Sport Psychology, 10, 297-318. doi:10.1080/10413209808406395 
Table 1

Summary of Studies Included in the Review

\begin{tabular}{|c|c|c|c|c|c|c|}
\hline Author(s) & Purpose & Participants & Sport(s) & Design & Data collection & Main findings \\
\hline $\begin{array}{l}\text { Chroni, } \\
\text { Abrahamsen, } \\
\text { and } \\
\text { Hemmestad } \\
(2016)\end{array}$ & $\begin{array}{l}\text { Explore stress } \\
\text { experiences of } \\
\text { coaches }\end{array}$ & $\begin{array}{l}N=7 \text { ( } 7 \text { males }), \\
\text { age range of } \\
\text { coaches }=28-53 \\
\text { years, } \\
\text { coaching } \\
\text { experience } \\
\text { range }=4-30 \\
\text { years, } \\
\text { type of } \\
\text { participants = } \\
\text { coaches, } \\
\text { Olympic } \\
\text { standard = not } \\
\text { reported, } \\
\text { country } \\
\text { represented = } \\
\text { Norway }\end{array}$ & $\begin{array}{l}\text { Not } \\
\text { reported }\end{array}$ & Qualitative & $\begin{array}{l}\text { Semi-structured } \\
\text { interviews }\end{array}$ & $\begin{array}{l}\text { The findings indicated that } \\
\text { coaches evaluated } \\
\text { stressors as manageable } \\
\text { (i.e. challenge appraisal) } \\
\text { due to their positive } \\
\text { response outcome } \\
\text { expectancies and their } \\
\text { specific defense } \\
\text { mechanisms. Further, } \\
\text { coaches were found to } \\
\text { have both high ego and } \\
\text { task orientations, cognitive } \\
\text { flexibility, coaching- } \\
\text { efficacy, and trait self- } \\
\text { confidence. }\end{array}$ \\
\hline $\begin{array}{l}\text { Currie and } \\
\text { Oates- } \\
\text { Wilding } \\
(2012)\end{array}$ & $\begin{array}{l}\text { Investigate the } \\
\text { factors that } \\
\text { contribute towards } \\
\text { coaching success } \\
\text { and goal } \\
\text { fulfilment }\end{array}$ & $\begin{array}{l}N=8 \text { ( } 8 \text { males), } \\
\text { age range of } \\
\text { coaches = not } \\
\text { reported, } \\
\text { mean years of } \\
\text { coaching } \\
\text { experience = } 15 \\
\text { years, } \\
\text { type of } \\
\text { participants }= \\
\text { coaches, } \\
\text { Olympic }\end{array}$ & $\begin{array}{l}\text { Beach } \\
\text { volleyball, } \\
\text { fencing, } \\
\text { modern } \\
\text { pentathlon, } \\
\text { water polo, } \\
\text { kayaking, } \\
\text { and } \\
\text { volleyball }\end{array}$ & Qualitative & $\begin{array}{l}\text { Unstructured } \\
\text { conversations }\end{array}$ & $\begin{array}{l}\text { Coaches identified } \\
\text { passion, commitment, } \\
\text { desire to succeed, past } \\
\text { athletic experience, and } \\
\text { focusing on individual } \\
\text { athlete's needs as integral } \\
\text { factors contributing to } \\
\text { their success. }\end{array}$ \\
\hline
\end{tabular}




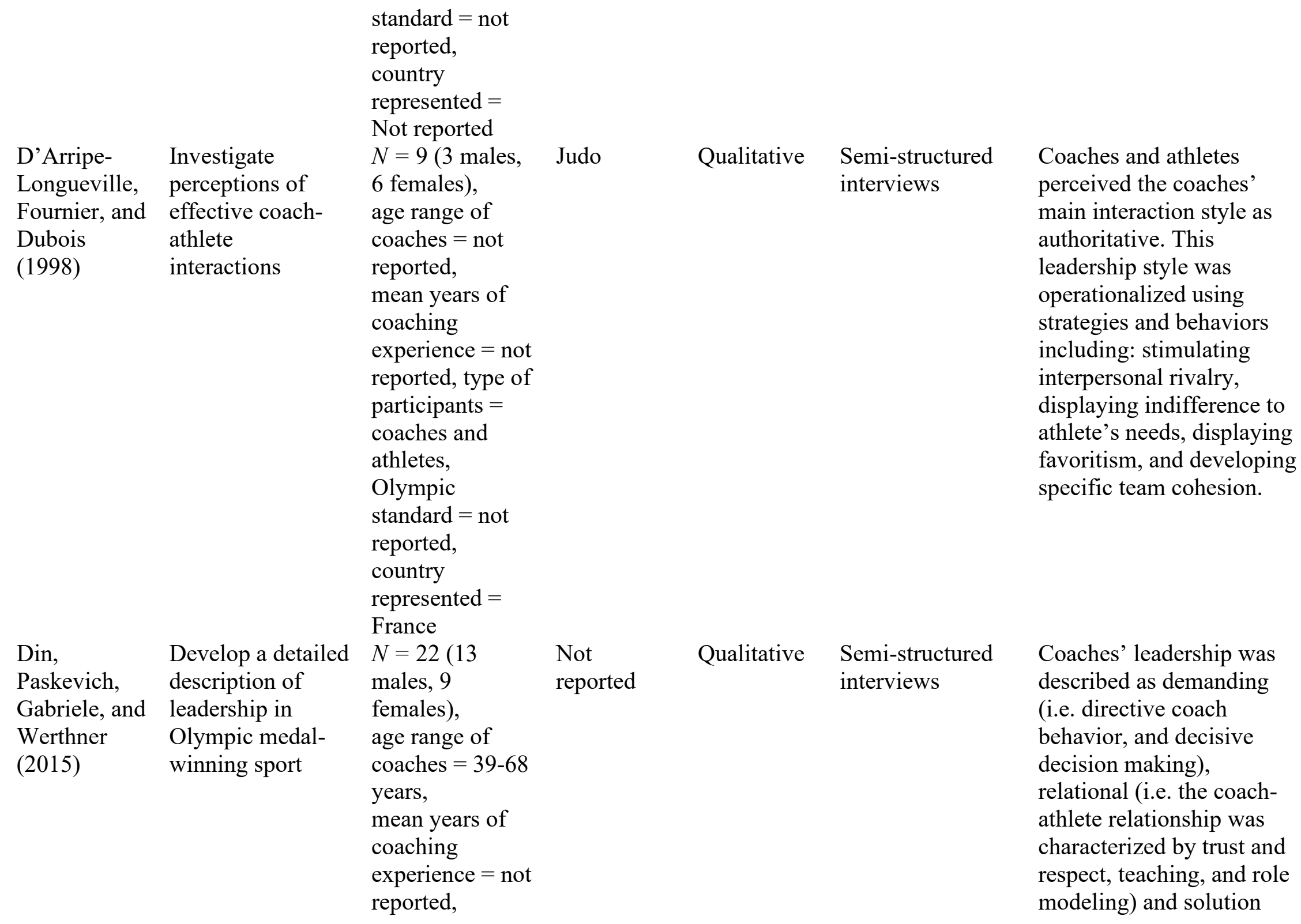




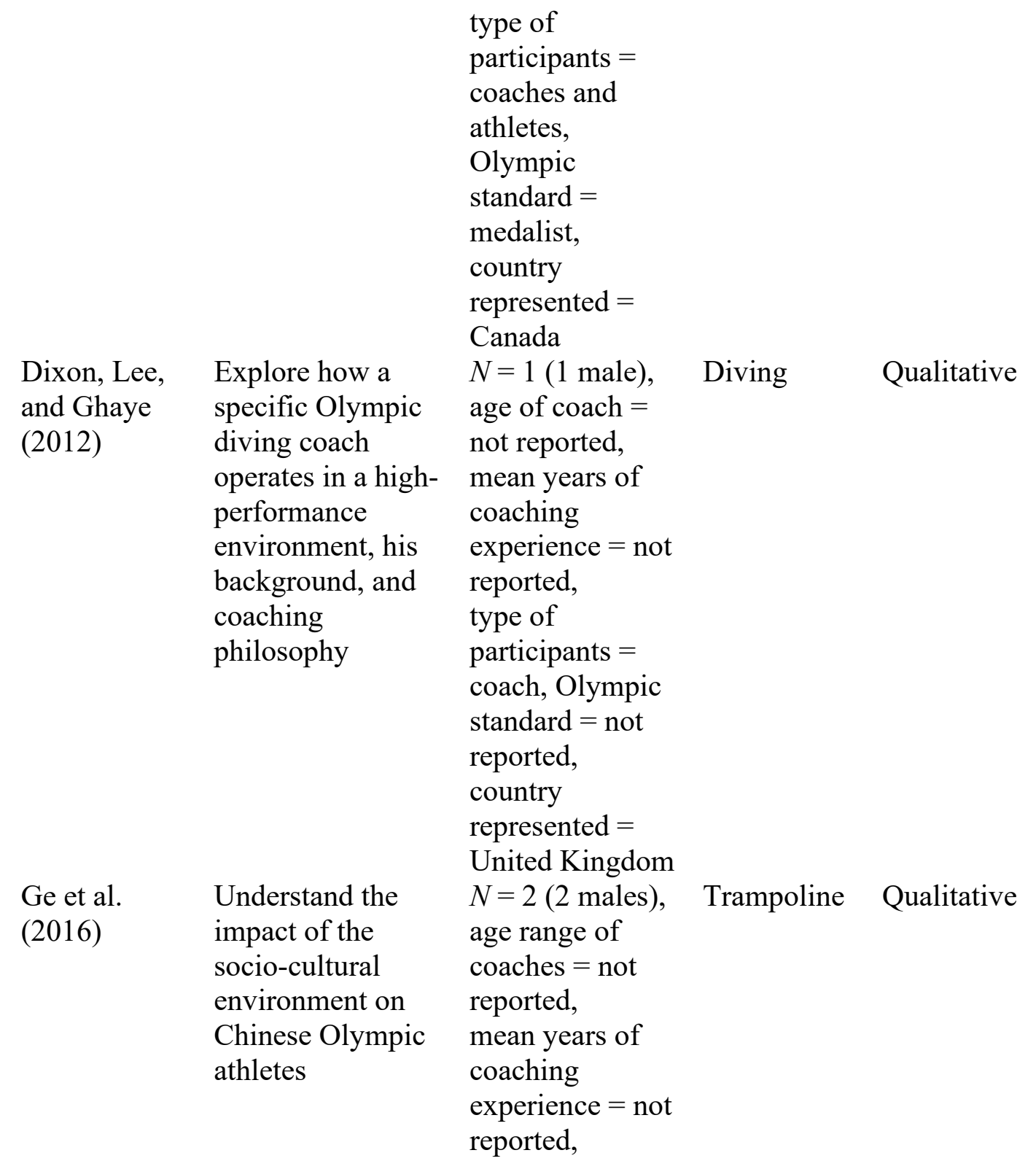

focused leadership (i.e. vision, structured learning culture, role clarity and recognition, and analytic tenacity).

\section{Reflexive conversation}

Discussion and co-authorship with two trampoline Olympic champions
The findings identified that the coach defined achievement as helping individuals achieve their personal best, utilized an athlete-centered, empowering, and understanding approach, and inspired athletes through positivity and persistence.

Within their environment, the Olympic athletes perceived medal-oriented pressure, and discussed the difficulties associated with their growing needs for autonomy. 


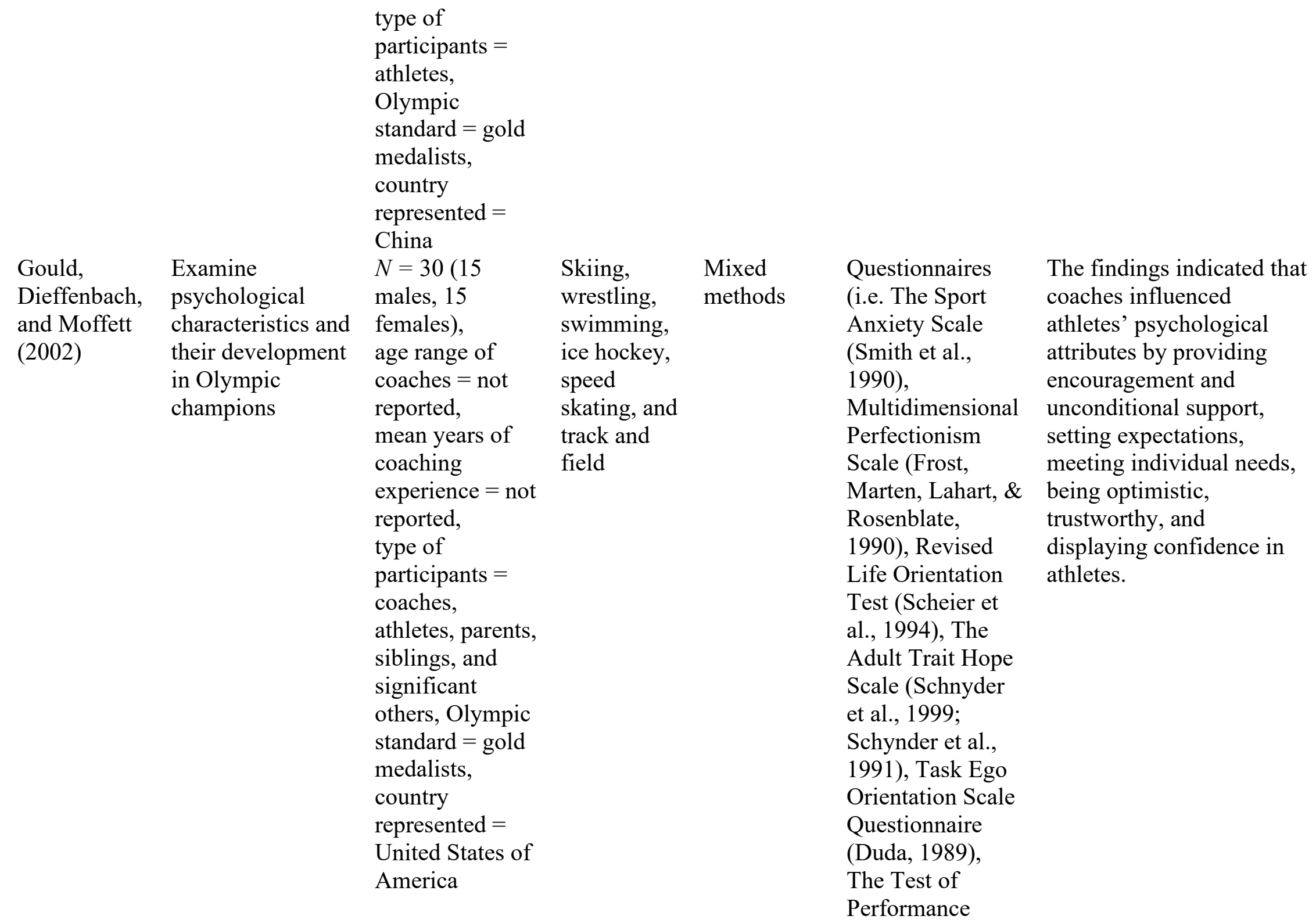




\begin{tabular}{|c|c|c|c|c|c|c|}
\hline & & & & & $\begin{array}{l}\text { Strategies } \\
\text { (Thomas et al., } \\
\text { 1999), and The } \\
\text { Athletic Coping } \\
\text { Skills Inventory } \\
\text { (Smith et al., } \\
\text { 1995) and semi- } \\
\text { structured } \\
\text { interviews }\end{array}$ & \\
\hline $\begin{array}{l}\text { Gould, } \\
\text { Greenleaf, } \\
\text { Guinan, } \\
\text { Dieffenbach, } \\
\text { and McCann } \\
(2001)\end{array}$ & $\begin{array}{l}\text { Examine } \\
\text { performance } \\
\text { related lessons } \\
\text { from Summer and } \\
\text { Winter Olympic } \\
\text { Games }\end{array}$ & $\begin{array}{l}N=444 \text { (not } \\
\text { reported), } \\
\text { age range of } \\
\text { coaches = not } \\
\text { reported, } \\
\text { mean years of } \\
\text { coaching } \\
\text { experience = not } \\
\text { reported, } \\
\text { type of } \\
\text { participants = } \\
\text { coaches and } \\
\text { athletes, } \\
\text { Olympic } \\
\text { standard = not } \\
\text { reported, } \\
\text { country } \\
\text { represented = } \\
\text { United States of } \\
\text { America }\end{array}$ & $\begin{array}{l}\text { Not } \\
\text { reported }\end{array}$ & $\begin{array}{l}\text { Mixed } \\
\text { methods }\end{array}$ & $\begin{array}{l}\text { Questionnaires } \\
\text { (i.e. Atlanta } \\
\text { survey, and } \\
\text { Nagano survey) } \\
\text { and individual } \\
\text { and focus group } \\
\text { interviews }\end{array}$ & $\begin{array}{l}\text { Coaches and athletes } \\
\text { identified many lessons for } \\
\text { the future, including the } \\
\text { importance of trust and } \\
\text { team cohesion, detailed } \\
\text { planning, enhanced fun } \\
\text { and enjoyment during } \\
\text { trials, and coach mental } \\
\text { preparation strategies } \\
\text { centering around } \\
\text { coaching-efficacy and } \\
\text { coping. }\end{array}$ \\
\hline $\begin{array}{l}\text { Gould, } \\
\text { Greenleaf, } \\
\text { Chung, and }\end{array}$ & $\begin{array}{l}\text { Examine the } \\
\text { variables } \\
\text { perceived to have } \\
\text { affected U.S. }\end{array}$ & $\begin{array}{l}N=379(293 \\
\text { males, } 86 \\
\text { females })\end{array}$ & $\begin{array}{l}\text { Not } \\
\text { reported }\end{array}$ & Quantitative & $\begin{array}{l}\text { Surveys (i.e. } \\
\text { USOC Atlanta } \\
\text { Olympic Coach } \\
\text { Survey, and }\end{array}$ & $\begin{array}{l}\text { The performance } \\
\text { influencing variables } \\
\text { included positive coach- } \\
\text { athlete relationships, }\end{array}$ \\
\hline
\end{tabular}




\section{Guinan}

(2002)

Gould,

Guinan,

Greenleaf, and Chung (2002)

Olympic athlete
performance

age range of

coaches $=$ not

reported,

mean years of

coaching

experience $=$ not

reported, type of

participants $=$

athletes,

Olympic

standard $=$ not

reported,

country

represented $=$

United States of

America

Examine variables

perceived to have

influenced athlete

performance and

coach

effectiveness in

Olympic

competition

\section{$N=65$ (53}

males, 12

females),

age range of

coaches $=28-65$

years,

mean years of

coaching

experience $=$

17.29 years,

type of

participants $=$

coaches,

Olympic

standard $=$ not

reported,

country
USOC Nagano

Olympic Coach

Survey)

\section{Not}

reported

Quantitative

\section{Surveys (i.e. U.S. Atlanta Olympic \\ Games Athlete}

Survey, and U.S. Olympic Games

Nagano Athlete

Survey) coaches' ability to withstand pressure and crises, and coaches' expectations.
Variables perceived to have positively influenced athlete's performance included coaches' consistency of behavior, coping, setting realistic expectations, making fair but decisive decisions, and being trustworthy. 


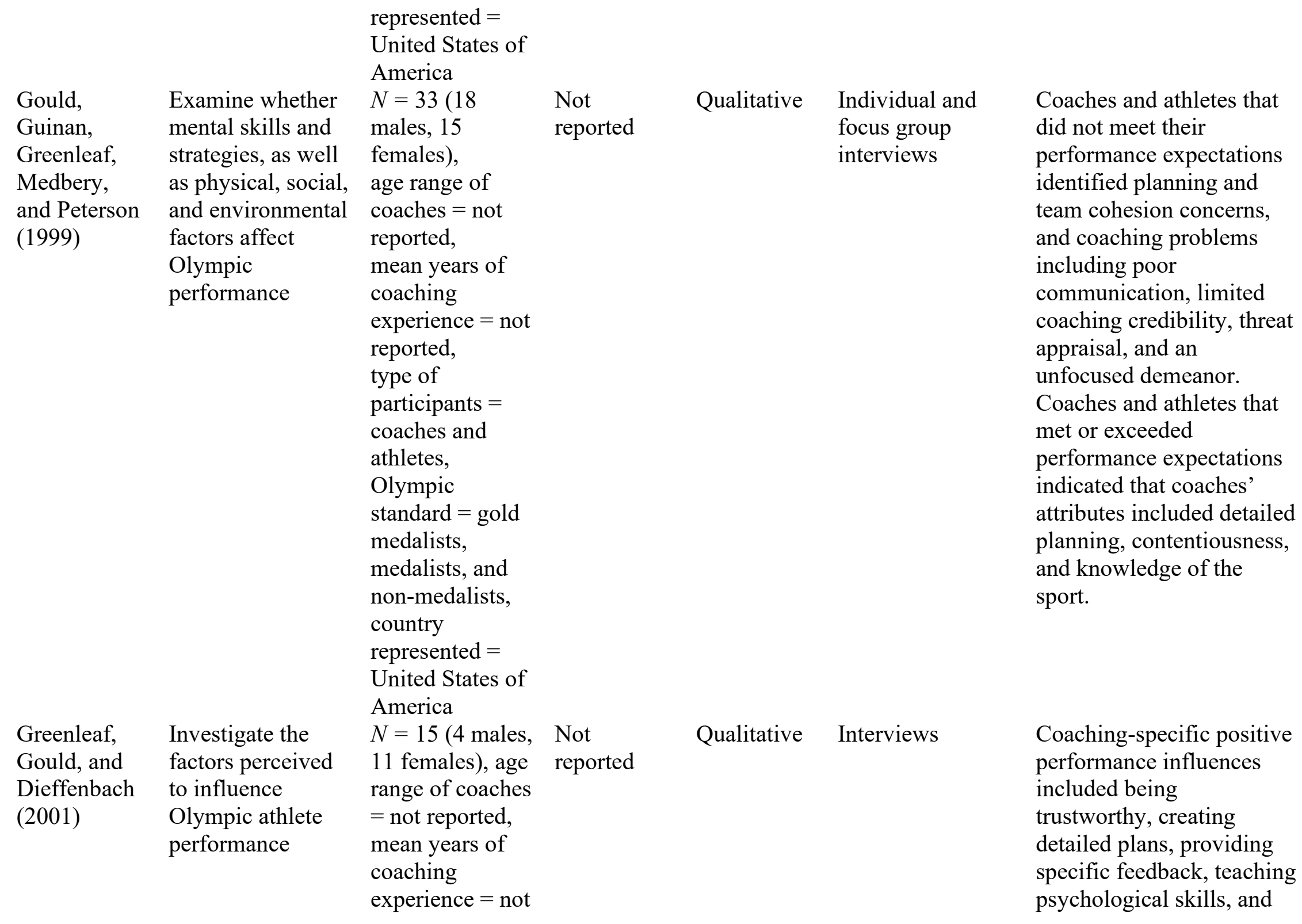




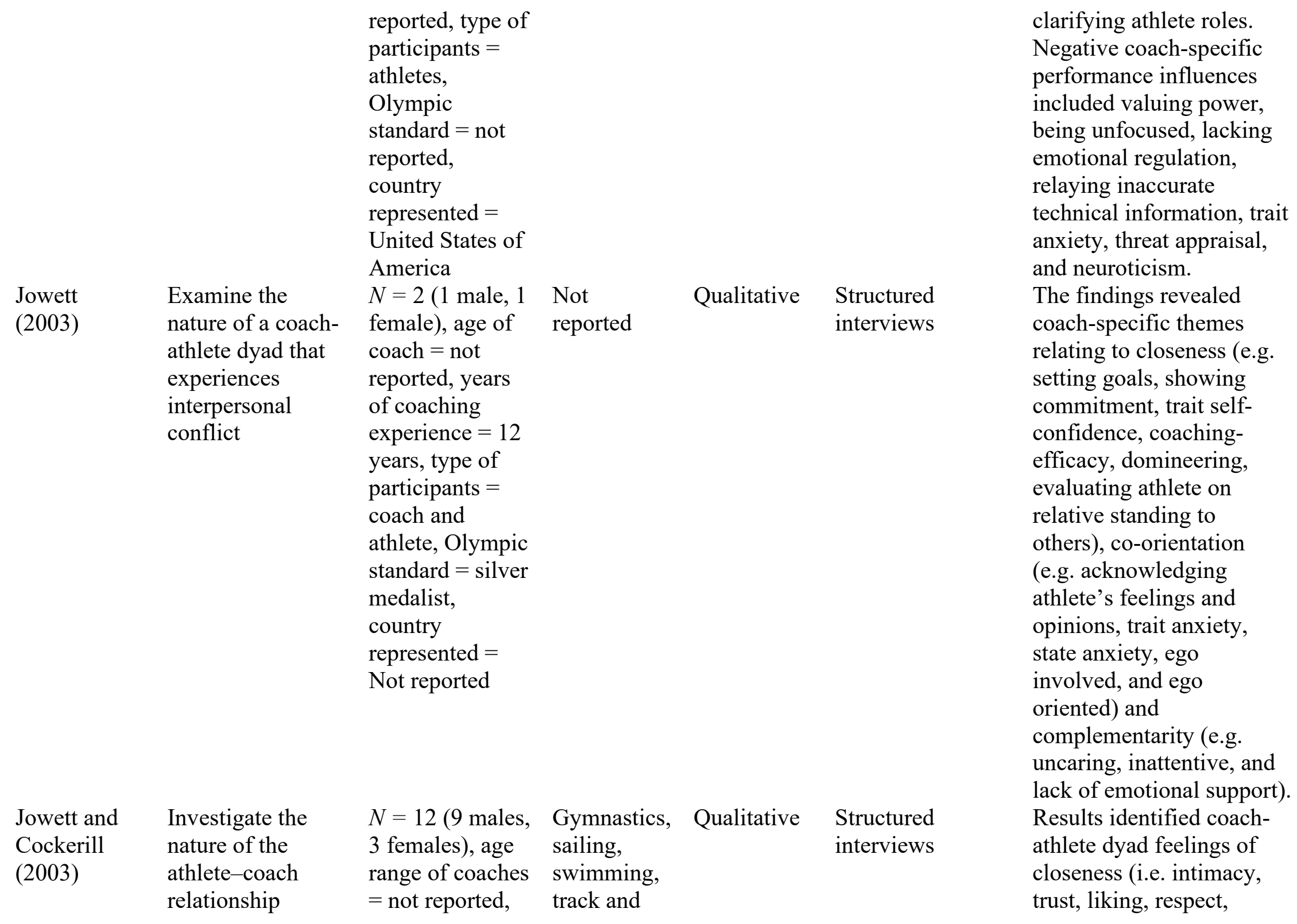




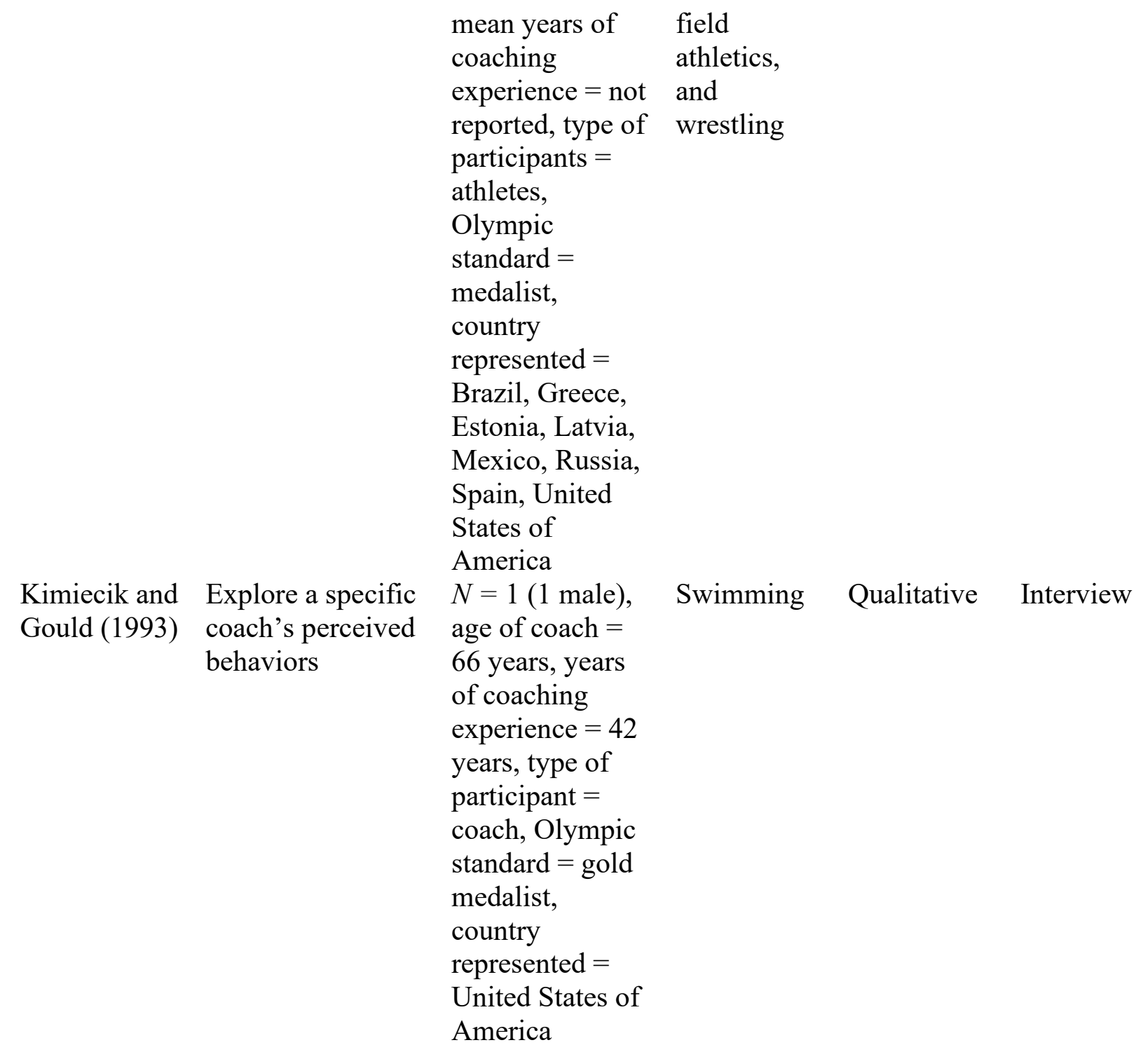

belief, and commitment), co-orientation (i.e. information exchange, common goals, and influence) and complementarity (i.e. roles and tasks, and support).

Findings revealed that the coach communicated enthusiasm, showed concern and understanding, demonstrated state and trait emotional intelligence, tailored communication to athletes, set realistic goals, showed cognitive flexibility, provided positive and negative feedback, reinforced athlete's selfbelief, and was intrinsically motivated. 


\begin{tabular}{|c|c|c|c|c|c|c|}
\hline $\begin{array}{l}\text { Lyons, } \\
\text { Rynee, and } \\
\text { Mallett } \\
(2012)\end{array}$ & $\begin{array}{l}\text { Examine coach- } \\
\text { athlete } \\
\text { interactions, with } \\
\text { a particular } \\
\text { interest in the } \\
\text { implementation of } \\
\text { autonomy } \\
\text { supportive } \\
\text { coaching } \\
\text { behaviors }\end{array}$ & $\begin{array}{l}N=4 \text { (1 male, } 3 \\
\text { females), age of } \\
\text { coach = not } \\
\text { reported, mean } \\
\text { years of } \\
\text { coaching } \\
\text { experience = } 17 \\
\text { years, type of } \\
\text { participants = } \\
\text { coach and } \\
\text { athletes, } \\
\text { Olympic } \\
\text { standard = not } \\
\text { reported, } \\
\text { country } \\
\text { represented = } \\
\text { Not reported }\end{array}$ & $\begin{array}{l}\text { Olympic ski } \\
\text { cross }\end{array}$ & Qualitative & $\begin{array}{l}\text { Semi-structured } \\
\text { interviews }\end{array}$ & $\begin{array}{l}\text { Within their environment, } \\
\text { coaches and athletes } \\
\text { identified the presence of } \\
\text { autonomy-supportive } \\
\text { coaching behaviors, the } \\
\text { coach's autonomy } \\
\text { supporting motivational } \\
\text { style, both coach and } \\
\text { athlete preferences for } \\
\text { autonomy supporting } \\
\text { behaviors, and the } \\
\text { importance of the } \\
\text { psychological need of } \\
\text { relatedness. }\end{array}$ \\
\hline $\begin{array}{l}\text { Mallett } \\
(2005)\end{array}$ & $\begin{array}{l}\text { Reports on the } \\
\text { application of } \\
\text { self-determination } \\
\text { theory to coaching } \\
\text { elite athletes }\end{array}$ & $\begin{array}{l}N=1(1 \text { male }), \\
\text { age of coach = } \\
\text { not reported, } \\
\text { mean years of } \\
\text { coaching } \\
\text { experience = not } \\
\text { reported, type of } \\
\text { participants = } \\
\text { coach, Olympic } \\
\text { standard = } \\
\text { finalist, country } \\
\text { represented = } \\
\text { Australia }\end{array}$ & $\begin{array}{l}\text { Track and } \\
\text { field } \\
\text { athletics }\end{array}$ & Qualitative & Case study & $\begin{array}{l}\text { Findings revealed that the } \\
\text { participant coach's task } \\
\text { orientation and autonomy } \\
\text { supporting behaviors } \\
\text { promoted an adaptive and } \\
\text { enjoyable training } \\
\text { environment, which was } \\
\text { proposed to optimize } \\
\text { athletes' performances. }\end{array}$ \\
\hline $\begin{array}{l}\text { Mallett and } \\
\text { Coulter } \\
(2016)\end{array}$ & $\begin{array}{l}\text { Examine the } \\
\text { personality (i.e. } \\
\text { dispositional }\end{array}$ & $\begin{array}{l}N=1(1 \text { male }) \\
\text { age of coach }= \\
\text { not reported, }\end{array}$ & $\begin{array}{l}\text { Not } \\
\text { reported }\end{array}$ & $\begin{array}{l}\text { Mixed } \\
\text { methods }\end{array}$ & $\begin{array}{l}\text { Questionnaires } \\
\text { (i.e. NEO-FFI-3, } \\
\text { self and observer }\end{array}$ & $\begin{array}{l}\text { Results demonstrated that } \\
\text { the coach was emotionally } \\
\text { stable, agreeable, }\end{array}$ \\
\hline
\end{tabular}


traits, personal strivings, and narrative identify) of a successful Olympic coach

mean years of

coaching

experience $=30$

years, type of

participant $=$

coach, Olympic

standard $=$

multiple

medalist,

country

represented $=$

Not reported

\begin{tabular}{|c|c|c|c|c|c|}
\hline $\begin{array}{l}\text { Olusoga, } \\
\text { Maynard, } \\
\text { Hays, and } \\
\text { Butt (2012) }\end{array}$ & $\begin{array}{l}\text { Explored Olympic } \\
\text { coaches' } \\
\text { perceptions of the } \\
\text { factors that } \\
\text { enabled them to } \\
\text { coach successfully } \\
\text { in a stressful } \\
\text { Olympic } \\
\text { environment }\end{array}$ & $\begin{array}{l}N=8 \text { ( } 8 \text { males), } \\
\text { age range of } \\
\text { coaches }=33-53 \\
\text { years, mean } \\
\text { years of } \\
\text { coaching } \\
\text { experience = } \\
13.1 \text { years, type } \\
\text { of participants = } \\
\text { coaches, } \\
\text { Olympic } \\
\text { standard = not } \\
\text { reported, } \\
\text { country } \\
\text { represented = } \\
\text { United Kingdom }\end{array}$ & $\begin{array}{l}\text { Not } \\
\text { reported }\end{array}$ & Qualitative & $\begin{array}{l}\text { Semi-structured } \\
\text { interviews }\end{array}$ \\
\hline
\end{tabular}

reports (Costa \&

McRae, 2010)

and Personal

Strivings

(Emmons, 1989))

and semi-

structured

interview nited Kingdom conscientious, open to new experiences, optimistic, passionate, task and ego oriented, extrinsically motivated, utilized emotion-focused coping, reinforced athlete selfbelief, demonstrated otherefficacy, hardy, emotional intelligent, aimed to help and develop others, and strived for power and achievement.

Coaches reported that psychological attributes (i.e. emotional control, perception, confidence, athlete focus,

communication, focus, passion, support, commitment, consistency, and fun), preparation (i.e. strategic approach, lifestyle choices, previous experience, contingency planning, team preparation, and athlete preparation), and coping (i.e. coach-specific strategies, team support, taking time out, drinking, and psychological skills) were essential for their 


\begin{tabular}{|c|c|c|c|c|c|c|}
\hline $\begin{array}{l}\text { Pensgaard } \\
\text { and Roberts } \\
(2000)\end{array}$ & $\begin{array}{l}\text { Examine athlete } \\
\text { perceptions of } \\
\text { distress, with } \\
\text { particular } \\
\text { attention paid to } \\
\text { the relative } \\
\text { importance of } \\
\text { dispositional and } \\
\text { situational factors }\end{array}$ & $\begin{array}{l}N=69(49 \\
\text { males, } 20 \\
\text { females }) \text {, age } \\
\text { range of coaches } \\
\text { = not reported, } \\
\text { mean years of } \\
\text { coaching } \\
\text { experience = not } \\
\text { reported, type of } \\
\text { participants = } \\
\text { athletes, } \\
\text { Olympic } \\
\text { standard = not } \\
\text { reported, } \\
\text { country } \\
\text { represented = } \\
\text { Norway }\end{array}$ & $\begin{array}{l}\text { Not } \\
\text { reported }\end{array}$ & Quantitative & $\begin{array}{l}\text { Questionnaires } \\
\text { (i.e. Perceived } \\
\text { Motivational } \\
\text { Climate in Sport } \\
\text { Questionnaire } \\
\text { (Seifriz et al., } \\
\text { 1992), Perception } \\
\text { of Success } \\
\text { Questionnaire } \\
\text { (Roberts \& } \\
\text { Ommundsen, } \\
\text { 1996; Roberts et } \\
\text { al., 1998), } \\
\text { Sources of } \\
\text { Distress } \\
\text { Questionnaire } \\
\text { (based on Scanlan } \\
\text { et al., 1991; } \\
\text { Perception of } \\
\text { Ability (based on } \\
\text { Nicholls et al., } \\
\text { 1990). }\end{array}$ & $\begin{array}{l}\text { Findings revealed the } \\
\text { presence of both } \\
\text { performance and mastery } \\
\text { climates, indicating } \\
\text { coaches possessed both } \\
\text { task and ego orientations. } \\
\text { Performance climates were } \\
\text { associated with athlete } \\
\text { cognitive stress, and the } \\
\text { coach was perceived to be } \\
\text { one sources of this } \\
\text { distress. }\end{array}$ \\
\hline $\begin{array}{l}\text { Pensgaard } \\
\text { and Roberts } \\
(2002)\end{array}$ & $\begin{array}{l}\text { Understand the } \\
\text { importance of a } \\
\text { mastery climate } \\
\text { and the role of the } \\
\text { coach in creating } \\
\text { the climate }\end{array}$ & $\begin{array}{l}N=7 \text { ( } 5 \text { males, } \\
2 \text { females), age } \\
\text { range of coaches } \\
=\text { not reported, } \\
\text { mean years of } \\
\text { coaching } \\
\text { experience = not } \\
\text { reported, type of } \\
\text { participants = }\end{array}$ & $\begin{array}{l}\text { Not } \\
\text { reported }\end{array}$ & $\begin{array}{l}\text { Mixed } \\
\text { methods }\end{array}$ & $\begin{array}{l}\text { Questionnaires } \\
\text { (i.e. Perception of } \\
\text { Success } \\
\text { Questionnaire } \\
\text { (Roberts et al., } \\
\text { 1998) and } \\
\text { Perception of } \\
\text { Motivational } \\
\text { Climate }\end{array}$ & $\begin{array}{l}\text { Athletes reported a high } \\
\text { mastery climate and low } \\
\text { performance climate. } \\
\text { Further, they stated a } \\
\text { preference for a supportive } \\
\text { and caring climate which } \\
\text { coaches were instrumental } \\
\text { in creating. Coaches } \\
\text { demonstrated emotional }\end{array}$ \\
\hline
\end{tabular}




\begin{tabular}{|c|c|c|c|c|c|c|}
\hline & & $\begin{array}{l}\text { athletes, } \\
\text { Olympic } \\
\text { standard = not } \\
\text { reported, } \\
\text { country } \\
\text { represented = } \\
\text { Norway }\end{array}$ & & & $\begin{array}{l}\text { Questionnaire } \\
\text { (Seifriz et al., } \\
\text { 1992), and } \\
\text { structured } \\
\text { interviews }\end{array}$ & $\begin{array}{l}\text { intelligence and } \\
\text { understanding, tailored } \\
\text { their communication to } \\
\text { athletes, utilized corrective } \\
\text { feedback, provided } \\
\text { praise/encouragement, and } \\
\text { were task oriented. }\end{array}$ \\
\hline $\begin{array}{l}\text { Phillippe and } \\
\text { Seiler (2006) }\end{array}$ & $\begin{array}{l}\text { Study athletes' } \\
\text { perceptions of the } \\
\text { quality of their } \\
\text { relationships with } \\
\text { their coaches }\end{array}$ & $\begin{array}{l}N=5 \text { (5 males), } \\
\text { age range of } \\
\text { coaches = not } \\
\text { reported, mean } \\
\text { years of } \\
\text { coaching } \\
\text { experience = not } \\
\text { reported, type of } \\
\text { participants = } \\
\text { athletes, } \\
\text { Olympic } \\
\text { standard = not } \\
\text { reported, } \\
\text { country } \\
\text { represented = } \\
\text { Switzerland }\end{array}$ & Swimming & Qualitative & $\begin{array}{l}\text { Structured } \\
\text { interviews }\end{array}$ & $\begin{array}{l}\text { Athletes reported that } \\
\text { maintaining good } \\
\text { relationships with their } \\
\text { coach was a priority, and } \\
\text { the elements of an } \\
\text { effective coach-athlete } \\
\text { relationship were as } \\
\text { follows: closeness (i.e. } \\
\text { respect, esteem, } \\
\text { admiration, appreciation, } \\
\text { professional relationship, } \\
\text { friendship, and love), co- } \\
\text { orientation (i.e. technical } \\
\text { communication, savoir- } \\
\text { être, verbal interchange, } \\
\text { problem resolution, } \\
\text { common goals, and respect } \\
\text { the goals set), and } \\
\text { complementarity (i.e. } \\
\text { seeing the positive side, } \\
\text { using the differences, } \\
\text { assuming responsibilities, } \\
\text { and respecting the task). }\end{array}$ \\
\hline $\begin{array}{l}\text { Seanor, } \\
\text { Schinke, } \\
\text { Stamulova, }\end{array}$ & $\begin{array}{l}\text { Investigate how } \\
\text { athletes' training } \\
\text { environments }\end{array}$ & $\begin{array}{l}N=3 \text { ( } 2 \text { males, } \\
1 \text { female }), \text { age } \\
\text { range of coaches }\end{array}$ & Trampoline & Qualitative & $\begin{array}{l}\text { Mobile } \\
\text { conversational } \\
\text { interview }\end{array}$ & $\begin{array}{l}\text { Results revealed coaches } \\
\text { displayed an autonomy } \\
\text { supporting motivational }\end{array}$ \\
\hline
\end{tabular}




\begin{tabular}{|c|c|c|c|c|c|}
\hline $\begin{array}{l}\text { Ross, and } \\
\text { Kpazai } \\
(2017)\end{array}$ & $\begin{array}{l}\text { influence their } \\
\text { subsequent } \\
\text { Olympic } \\
\text { accomplishments }\end{array}$ & $\begin{array}{l}=\text { not reported, } \\
\text { mean years of } \\
\text { coaching } \\
\text { experience = not } \\
\text { reported, type of } \\
\text { participants = } \\
\text { coach, assistant } \\
\text { coach, and } \\
\text { athlete, Olympic } \\
\text { standard = } \\
\text { medalist, } \\
\text { country } \\
\text { represented = } \\
\text { Canada }\end{array}$ & & & \\
\hline $\begin{array}{l}\text { Sullivan and } \\
\text { Nashman } \\
\text { (1993) }\end{array}$ & $\begin{array}{l}\text { Examine Olympic } \\
\text { coaches' } \\
\text { perceptions of } \\
\text { job-related } \\
\text { satisfactions and } \\
\text { stressors }\end{array}$ & $\begin{array}{l}N=10 \text { ( } 9 \text { males, } \\
1 \text { female }), \text { age } \\
\text { range of coaches } \\
=35-65 \text { years, } \\
\text { mean years of } \\
\text { coaching } \\
\text { experience = not } \\
\text { reported, type of } \\
\text { participants = } \\
\text { coaches, } \\
\text { Olympic } \\
\text { standard = not } \\
\text { reported, } \\
\text { country } \\
\text { represented = } \\
\text { United States of } \\
\text { America }\end{array}$ & $\begin{array}{l}\text { Water polo, } \\
\text { bobsleigh, } \\
\text { volleyball, } \\
\text { baseball, } \\
\text { soccer, } \\
\text { basketball, } \\
\text { ice hockey, } \\
\text { and } \\
\text { handball }\end{array}$ & Qualitative & $\begin{array}{l}\text { Structured } \\
\text { interview }\end{array}$ \\
\hline
\end{tabular}

style, provided choice to athletes, asked facilitative questions, monitored sport science support, and created an enjoyable training environment.

Findings described coaches as exhibiting stress-induced behaviors, and under-utilizing stressreduction techniques. 


\begin{tabular}{|c|c|c|c|c|c|c|}
\hline $\begin{array}{l}\text { Trzaskoma- } \\
\text { Bicsérdy, } \\
\text { Bognár, } \\
\text { Révéz, and } \\
\text { Géczi (2007) }\end{array}$ & $\begin{array}{l}\text { Examine } \\
\text { successful coach- } \\
\text { athlete } \\
\text { relationships }\end{array}$ & $\begin{array}{l}N=5 \text { ( } 5 \text { males }), \\
\text { age range of } \\
\text { coaches = not } \\
\text { reported, mean } \\
\text { years of } \\
\text { coaching } \\
\text { experience = not } \\
\text { reported, type of } \\
\text { participants = } \\
\text { coaches and } \\
\text { athletes, } \\
\text { Olympic } \\
\text { standard = } \\
\text { medalist, } \\
\text { country } \\
\text { represented = } \\
\text { Hungary }\end{array}$ & $\begin{array}{l}\text { Kayaking, } \\
\text { swimming, } \\
\text { and } \\
\text { wrestling }\end{array}$ & Qualitative & $\begin{array}{l}\text { Semi-structured } \\
\text { interviews }\end{array}$ & $\begin{array}{l}\text { Results identified that } \\
\text { successful coach-athlete } \\
\text { relationships were } \\
\text { primarily contingent upon } \\
\text { the coach tailoring their } \\
\text { approach to the specific } \\
\text { needs of the athlete. }\end{array}$ \\
\hline
\end{tabular}


Table 2

Mixed Methods Appraisal Tool Criteria

\begin{tabular}{|c|c|c|c|c|c|}
\hline $\begin{array}{c}\text { Screening } \\
\text { questions (for all } \\
\text { types) }\end{array}$ & Qualitative & $\begin{array}{l}\text { Quantitative } \\
\text { randomized } \\
\text { controlled (trials) }\end{array}$ & $\begin{array}{l}\text { Quantitative non- } \\
\text { randomized }\end{array}$ & $\begin{array}{l}\text { Quantitative } \\
\text { descriptive }\end{array}$ & Mixed methods \\
\hline
\end{tabular}

\begin{tabular}{ll}
\hline $\begin{array}{l}\text { A. Are there clear } \\
\text { qualitative and } \\
\text { quantitative } \\
\text { research questions } \\
\text { (or objectives), or a }\end{array}$ & $\begin{array}{l}\text { 1.1. Are the sources } \\
\text { of qualitative data } \\
\text { (archives, } \\
\text { decuments, }\end{array}$ \\
$\begin{array}{l}\text { informants, } \\
\text { observations) }\end{array}$ \\
methods question & $\begin{array}{l}\text { relevant to address } \\
\text { (or objective)? }\end{array}$ \\
& $\begin{array}{l}\text { question } \\
\text { (objective)? }\end{array}$
\end{tabular}

\begin{tabular}{|c|c|}
\hline $\begin{array}{l}\text { 2.1. Is there a clear } \\
\text { description of the } \\
\text { randomization (or } \\
\text { an appropriate } \\
\text { sequence } \\
\text { generation)? }\end{array}$ & $\begin{array}{l}\text { 3.1. Are } \\
\text { participants } \\
\text { (organizations) } \\
\text { recruited in a way } \\
\text { that minimizes } \\
\text { selection bias? }\end{array}$ \\
\hline
\end{tabular}

4.1. Is the sampling $\quad 5.1$. Is the mixed strategy relevant to methods research address the quantitative research question (quantitative aspect of the mixed methods question)? design relevant to address the qualitative and quantitative research questions question (objective)?

B. Do the collected data address the research question (objective)? E.g., consider whether the follow-up period is long enough for the outcome to occur (for longitudinal studies or study components).
1.2. Is the process for analyzing qualitative data relevant to address the research question (objective)?
2.2. Is there a clear description of the allocation concealment (or blinding when applicable)?

\subsection{Are}

measurements appropriate (clear origin, or validity known, or standard instrument; and absence of contamination between groups when appropriate) regarding the exposure/ intervention and outcomes?
4.2. Is the sample representative of the population understudy? (or objectives), or the qualitative and quantitative aspects of the mixed methods question (or objective)? 5.2. Is the integration of qualitative and quantitative data (or results) relevant to address the research question (objective)? 


\author{
1.3. Is appropriate \\ consideration given \\ to how findings \\ relate to the \\ context, e.g., the \\ setting, in which \\ the data were \\ collected?
}

\author{
1.4. Is appropriate \\ consideration given \\ to how findings \\ relate to \\ researchers' \\ influence, e.g., \\ through their \\ interactions with \\ participants?
}

2.3. Are there complete outcome data $(80 \%$ or above)?

2.4. Is there low withdrawal/drop-out (below 20\%)?
3.3. In the groups being compared (exposed vs. nonexposed; with intervention vs.

without; cases vs. controls), are the participants comparable, or do researchers take into account (control for) the difference between these groups? 3.4. Are there complete outcome data $(80 \%$ or above), and, when applicable, an acceptable response rate $(60 \%$ or above), or an acceptable followup rate for cohort studies (depending on the duration of follow-up)?
4.3. Are measurements appropriate (clear origin, or validity known, or standard instrument)? acceptable response rate $(60 \%$ or above)?

\subsection{Is there an}

5.3. Is appropriate consideration given to the limitations associated with this integration, e.g., the divergence of qualitative and quantitative data (or results) in a triangulation design? 
Table 3

Studies Included in the Review Scored Against MMAT Criteria

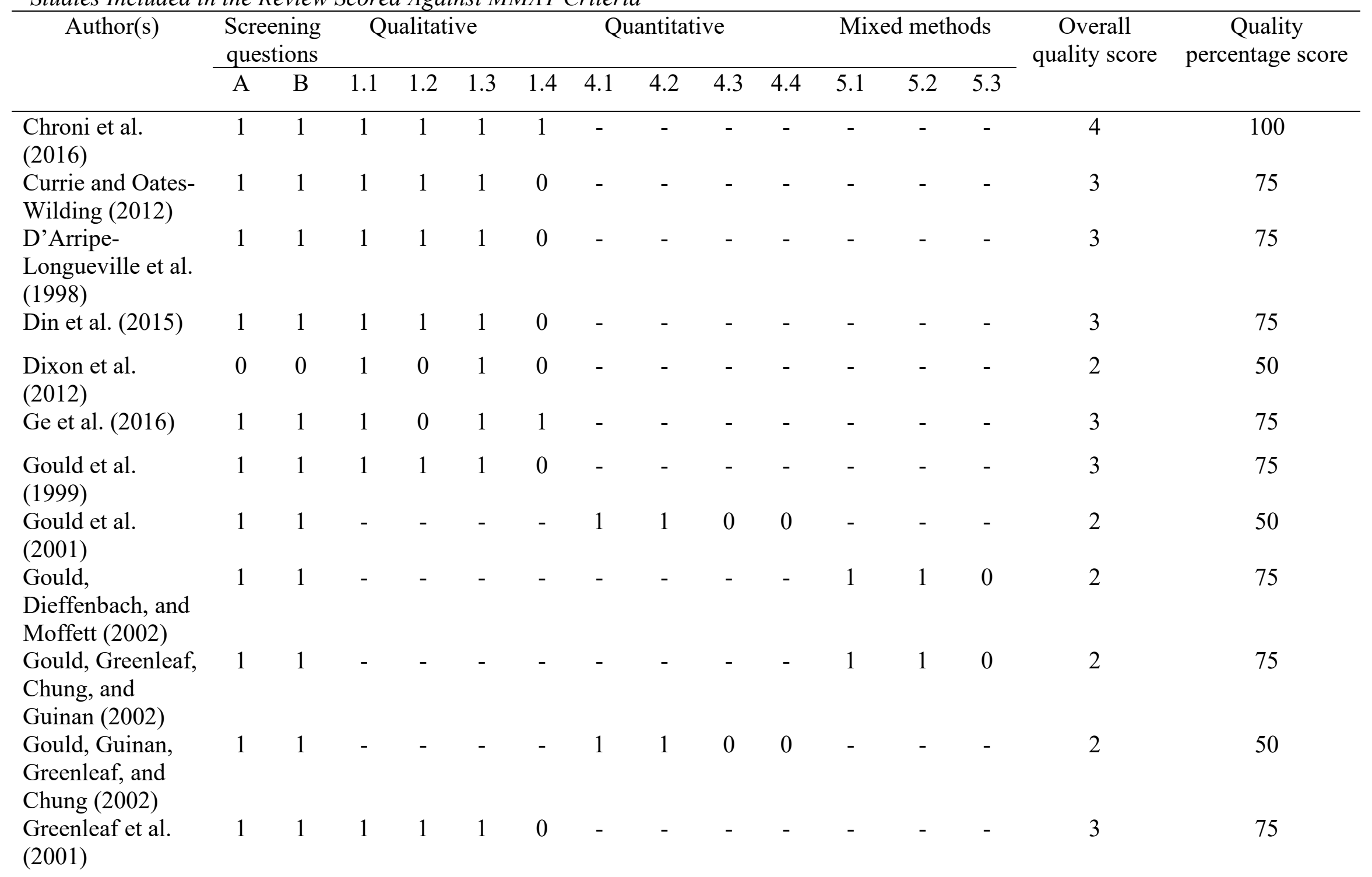




\begin{tabular}{|c|c|c|c|c|c|c|c|c|c|c|c|c|c|c|c|}
\hline Jowett (2003) & 1 & 1 & 1 & 1 & 1 & 0 & - & - & - & - & - & - & - & 3 & 75 \\
\hline $\begin{array}{l}\text { Jowett and } \\
\text { Cockerill (2003) }\end{array}$ & 1 & 1 & 1 & 1 & 1 & 0 & - & - & - & - & - & - & - & 3 & 75 \\
\hline $\begin{array}{l}\text { Kimiecik and } \\
\text { Gould (1987) }\end{array}$ & 1 & 1 & 1 & 0 & 0 & 0 & - & - & - & - & - & - & - & 1 & 25 \\
\hline $\begin{array}{l}\text { Lyons et al. } \\
(2012)\end{array}$ & 1 & 1 & 1 & 1 & 1 & 0 & - & - & - & - & - & - & - & 3 & 75 \\
\hline Mallett (2005) & 1 & 1 & 1 & 0 & 1 & 1 & - & - & - & - & - & - & - & 3 & 75 \\
\hline $\begin{array}{l}\text { Mallett and } \\
\text { Coulter (2016) }\end{array}$ & 1 & 1 & - & - & - & - & - & - & - & - & 1 & 1 & 0 & 2 & 75 \\
\hline $\begin{array}{l}\text { Olusoga et al. } \\
\text { (2012) }\end{array}$ & 1 & 1 & 1 & 1 & 1 & 0 & - & - & - & - & - & - & - & 3 & 75 \\
\hline $\begin{array}{l}\text { Pensgaard and } \\
\text { Roberts (2000) }\end{array}$ & 1 & 1 & - & - & - & - & 1 & 1 & 1 & 1 & - & - & - & 4 & 100 \\
\hline $\begin{array}{l}\text { Pensgaard and } \\
\text { Roberts (2002) }\end{array}$ & 1 & 1 & - & - & - & - & - & - & - & - & 1 & 1 & 0 & 2 & 75 \\
\hline $\begin{array}{l}\text { Phillippe and } \\
\text { Seiler (2006) }\end{array}$ & 1 & 1 & 1 & 1 & 1 & 0 & - & - & - & - & - & - & - & 3 & 75 \\
\hline $\begin{array}{l}\text { Seanor et al. } \\
(2017)\end{array}$ & 1 & 1 & 1 & 1 & 1 & 1 & - & - & - & - & - & - & - & 4 & 100 \\
\hline $\begin{array}{l}\text { Sullivan and } \\
\text { Nasham (1993) }\end{array}$ & 1 & 1 & 1 & 0 & 1 & 0 & - & - & - & - & - & - & - & 2 & 50 \\
\hline $\begin{array}{l}\text { Trzaskoma- } \\
\text { Bicsérdy et al. } \\
(2007)\end{array}$ & 1 & 1 & 1 & 1 & 1 & 0 & - & - & - & - & - & - & - & 3 & 75 \\
\hline $\begin{array}{l}\text { Percentage of } \\
\text { studies that met } \\
\text { relevant criteria }\end{array}$ & 96 & 96 & 100 & 72 & 94 & 22 & 100 & 100 & 33 & 33 & 100 & 100 & 0 & & \\
\hline
\end{tabular}

Note. $1=$ Yes; $0=$ No or insufficient information provided in the study; - = Criteria not relevant to the study. 


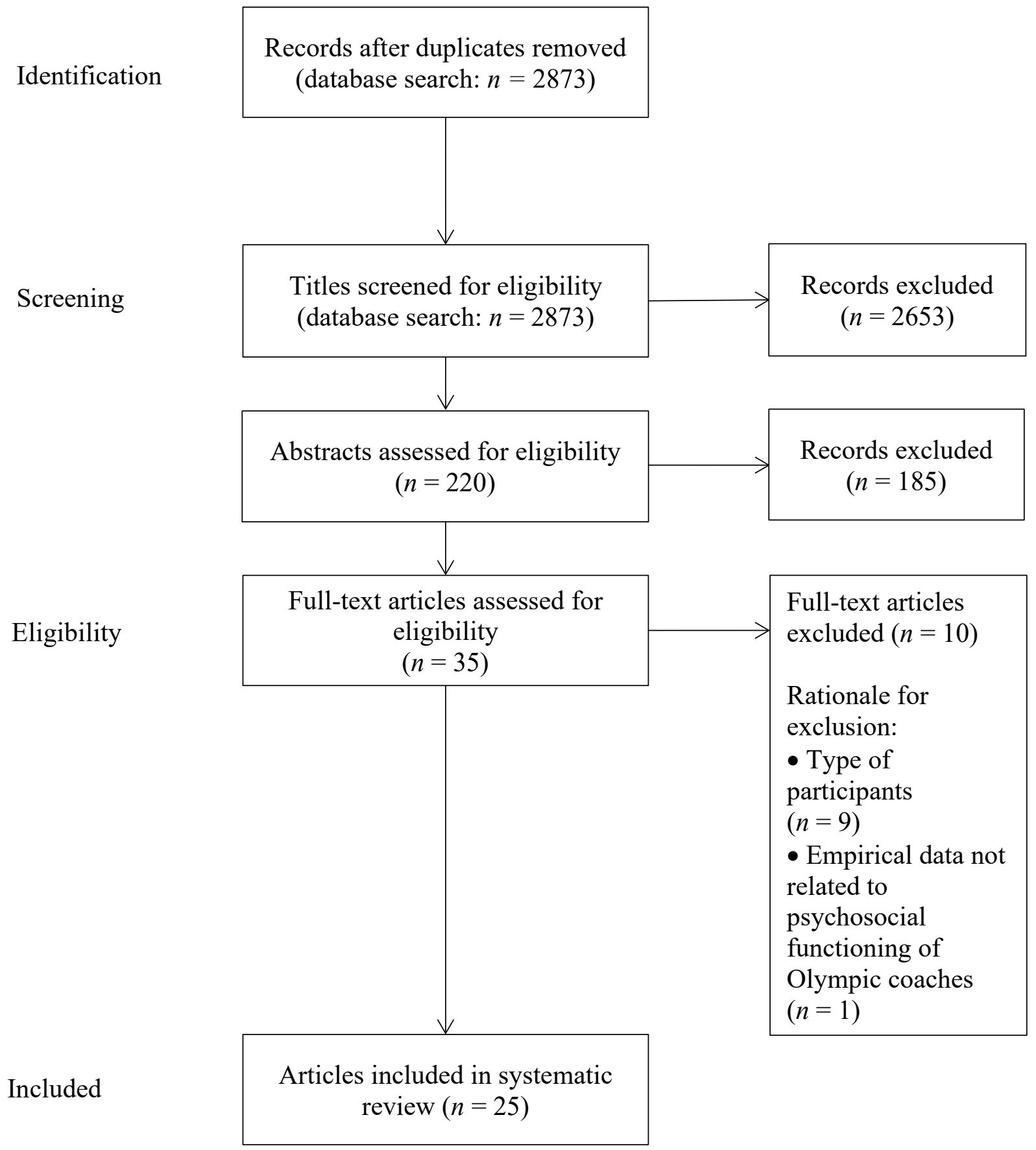

Figure 1. PRISMA (Preferred Reporting Items for Systematic Reviews and Meta-Analyses) flowchart. $N$ number of papers. 


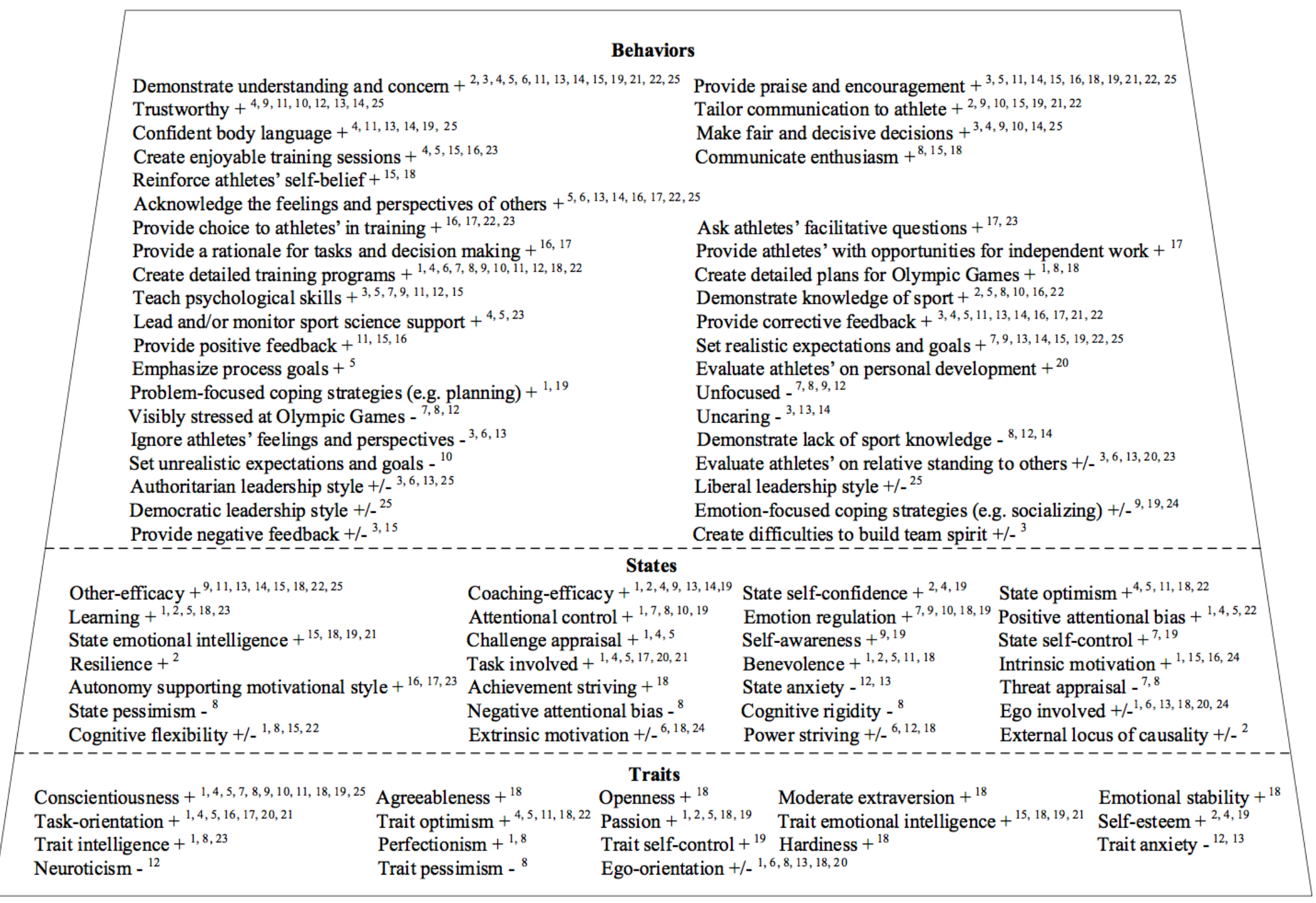


Figure 2. Psychosocial functioning of Olympic coaches and its perceived effect on athlete performance

Note. + denotes a perceived facilitative trait, state and/or behavior; - denotes a perceived debilitative trait, state and/or behavior; and +/- detonates a perceived non-categorized trait, state and/or behavior.

Reference numbers of studies that present data relating to this trait, state, and/or behavior: $1=$ Chroni et al. (2016); $2=$ Currie and Oates-Wilding (2012); 3 = D'Arripe-Longueville et al. (1998); 4 = Din et al. (2015); 5 = Dixon et al. (2012); 6= Ge et al. (2016); $7=$ Gould, Dieffenbach, and Moffett (2002); 8 = Gould et al. (1999); $9=$ Gould et al. (2001); 10 = Gould, Greenleaf, Chung, and Guinan (2002); 11 = Gould, Guinan, Greenleaf, and Chung (2002); $12=$ Greenleaf et al. (2001); $13=$ Jowett (2003); $14=$ Jowett and Cockerill (2003); 15 = Kimiecik and Gould (1993); $16=$ Lyons et al. (2012); $17=$ Mallett (2005); $18=$ Mallett and Coulter (2016); 19 = Olusoga et al. (2012); 20 = Pensgaard and Roberts (2000); $21=$ Pensgaard and Roberts (2002); $22=$ Phillippe and Seiler (2006); 23 = Seanor et al. (2017); 24 = Sullivan and Nashman (1993); 25 = Trzaskoma-Bicsérdy et al. (2007). 